\title{
WHEN THE SUPREME COURT RESTRICTS CONSTITUTIONAL RIGHTS, CAN CONGRESS SAVE US? \\ AN EXAMINATION OF SECTION 5 OF THE FOURTEENTH AMENDMENT
}

\section{MatT PaWA $†$}

One can hardly imagine this Court saying that because Congress is composed of individuals, individual rights guaranteed by the Bill of Rights are amply protected by the political process. ${ }^{1}$

As one cynic has said, with five votes anything is possible. ${ }^{2}$

\section{INTRODUCTION}

On June 27, 1991, New York Congressman Stephen Solarz addressed the House of Representatives and, in unusually harsh terms, denounced a recent Supreme Court decision. The decision, Employment Division v. Smith, ${ }^{3}$ had drastically reduced the right to the free exercise of religion. ${ }^{4}$ Solarz assailed Smith as a "dastardly and unprovoked attack on our first freedom ${ }^{n 5}$ and declared that Smith "must not be permitted to stand unchallenged." ${ }^{6}$ To counteract Smith, Solarz introduced a bill entitled the Religious Freedom Restoration Act (RFRA). ${ }^{7}$

At about the same time, Senator Edward Kennedy introduced a bill to eliminate racial bias in the imposition of the death penalty. Kennedy's bill, the Racial Justice Act (RJA), ${ }^{8}$ was designed to

† B.S. 1987, Cornell University; J.D. Candidate 1993, University of Pennsylvania. In memory of my father, Dr. Jay M. Pawa; and dedicated to my mother, Sandra K. Pawa, with infinite love.

Many thanks go to the following individuals: Elyse Rosenblum, Professor Seth Kreimer, Professor Douglas Laycock and Sean Lev.

${ }^{1}$ Garcia v. San Antonio Metro. Transit Auth., 469 U.S. 528, 565 n.8 (1985) (Powell, J., dissenting).

2 Antonin Scalia, The Rule of Law as a Law of Rules, 56 U. CHI. L. REv. 1175, 1185 (1989).

${ }^{3} 494$ U.S. 872 (1990).

4 See Religious Freedom Restoration Act of 1991: Hearings on H.R. 2797 Before the Subcomm. on Civil and Constitutional Rights of the House Comm. on the Judiciary, 102d Cong., 2d Sess. (1992) [hereinafter 1992 RFRA Hearings] (forthcoming 1993) (unpublished statements on file with author) (statement of Professor Douglas Laycock at 7) ("There simply is no substantive constitutional right to religious liberty any more.").

5137 CoNG. REC. E2422 (daily ed. June 27, 1991) (statement of Rep. Solarz).

6 Id.

${ }^{7}$ H.R. 2797, 102d Cong., 1st Sess. (1991).

${ }^{8}$ S. 1249, 102d Cong., 1st Sess. (1991). 
counteract McCleskey $v$. Kemp, ${ }^{9}$ a criminal case in which the Supreme Court found no violation of the right to equal protection of the laws despite statistical evidence showing that Georgia imposed the death penalty unequally according to race. "I believe that the McCleskey decision is a mistake," Kennedy told the Senate. ${ }^{10}$ "In its zeal to expedite proceedings in capital cases," Kennedy declared, the Court had "failed to recognize a glaring injustice that Congress should not tolerate, even if five Justices of the Supreme Court are willing to permit it." 11 After introducing statistical evidence showing racial disparities in capital sentencing in several states, Kennedy urged his colleagues to support the bill:

If we are to live up to our responsibility to fulfill the Constitution's promise of equal protection of the laws, we must ensure that race discrimination in capital punishment is eliminated. The Racial Justice Act is a practical step to achieve the goal of making our system of justice worthy of the name. ${ }^{12}$

During the same Congress, Senator Alan Cranston launched an attack on an abortion case, Webster $v$. Reproductive Health Services. ${ }^{13}$ According to Cranston, Webster "sent a shockwave through the country" by giving state legislatures "an open invitation to begin meddling with the freedom of individual women. ${ }^{n 14}$ Cranston described Webster as a "blow to all Americans who look to the Court to protect and preserve fundamental rights and liberties"15 and warned that the case threatened to turn the clock back to days when "unskilled, illegal abortionists preyed upon desperate women." 16 To prevent such a turn of events, Granston introduced the Freedom of Choice Act (FOCA), a bill designed to protect the right to abortion. ${ }^{17}$ Cranston defended Congress's competence to pass such a statute, claiming that "[i]t has long been recognized that Congress has the authority, under Section 5 of the 14th Amendment and other provisions of the Constitution to enact legislation to restrain states from denying due process and equal protection rights

9481 U.S. 279 (1987).

${ }^{10} 137$ CONG. REC. S7380 (daily ed. June 6, 1991) (statement of Sen. Kennedy).

11 Id.

$12 \mathrm{Id}$. at $\mathrm{S7381.}$

13492 U.S. 490 (1989).

14137 CONG. REC. S641 (daily ed. Jan. 14, 1991) (statement of Sen. Cranston).

${ }^{15} I d$.

${ }^{16} \mathrm{Id}$. at $\mathrm{S} 642$.

${ }^{17}$ S. 25, Version 1, 102d Cong., Ist Sess. (1991). 
to individuals. ${ }^{n 18}$ A year and a half later, Cranston returned to the Senate floor, warning of possibly dire results in another abortion case, Planned Parenthood v. Casey: ${ }^{19}$

Mr. President, we expect that the Supreme Court will act within the next few days, perhaps tomorrow, in a manner that will eliminate any meaningful constitutional protection of a woman's right to freedom of choice. It may be that the decision in Roe versus Wade is not wiped out wholly, but there will be more in the way of the direction of denying the right of choice to women. ${ }^{20}$

Anticipating the Court's decision in Casey, Cranston introduced a substitute bill which, among other things, specifically declared Congress's authority to enact the law. ${ }^{21}$

The RFRA, the RJA, and the FOCA have three things in common that set them apart from most bills: each is designed to increase the protection of a constitutional right; the Supreme Court has specifically declared that the Constitution does not protect that right to the extent the legislation would protect the right; and Congress's authority to enact each is based, at least in part, on Section 5 of the Fourteenth Amendment. ${ }^{22}$

Congressional attempts to legislate under the authority of section 5 have become frequent ${ }^{23}$ and it is not uncommon for

18137 Cong. REC. S641 (daily ed. Jan. 14, 1991) (statement of Sen. Cranston).

19112 S. Ct. 2791 (1992).

${ }^{20} 138$ CoNG. REC. S9027 (daily ed. June 25, 1992) (statement of Sen. Cranston).

21 See S. 25, Version 2, 102d Cong., 1st Sess. § 2(a)(4) (1991).

22 That the FOCA and the RJA are based on $\$ 5$ of the Fourteenth Amendment is evident from the text of the bills. See S. 25, 102d Cong., 2d Sess. § 2(a)(4) (1992) (relying explicitly on Congress's $\$ 5$ power); S. 1249, 102d Cong., lst Sess. §§ 2(1), (7) (1991) (same). That the RFRA is based on $\$ 5$ is evident from the congressional hearings on the bill. See 1992 RFRA Hearings, supra note 4 (statement of Professor Douglas Laycock at 24-30) (arguing that the RFRA is a lawful exercise of Congress's $\$ 5$ power).

${ }^{23}$ See, e.g., H.R. 2691, 102d Cong., 1st Sess. (1991) (prohibiting discrimination by the states on the basis of nonresidency in the licensing of dental health care professionals); H.R. 2190, 101st Cong., 2d Sess. (1990) (requiring the states to include voter registration applications as part of driver's license applications and establishing other national voter registration measures); Amendment No. 255 to S. 358, 101st Cong., 1st Sess. (1989) (prohibiting the counting of illegal aliens in the census population figures), in 135 CoNG. REC. S7879-80 (daily ed. July 13, 1989) (statement of Sen. Shelby); S. 377, 101st Cong., 1st Sess. (1989) (establishing a system of regional presidential primaries and caucuses); S. 327, 100th Cong., 1st Sess. (1987) (prohibiting lower federal courts from issuing injunctions using busing to integrate public schools); S. 158, 97th Cong., 1st Sess. (1981) (declaring that human life begins at conception for the purposes of the due process clause of the Fourteenth Amendment), in SENATE Judiciary Comm. Subcomm. ON SEParation of POWERs, 97Th Cong., 1st Sess., The Human Life Bill 1-2 (Comm. Print 1981). 
members of Congress to invoke section 5 when advocating their bills. ${ }^{24}$ Such legislation does not come from just the liberal end of the political spectrum: members of Congress have introduced bills to declare that embryos and fetuses are "persons" within the meaning of the Fourteenth Amendment; to prohibit federal courts from using busing to integrate public schools; and to exclude illegal aliens from the census population figures. ${ }^{25}$ Yet, within Congress there is no consensus on just how broadly the section 5 power extends. ${ }^{26}$

This Comment examines Section 5 of the Fourteenth Amendment to determine whether Congress may use its enforcement power to protect rights that the Court has specifically declined to protect. Part I of the Comment summarizes the Court's holdings in Smith, McCleskey, Webster, and Casey, and sets forth the legislative responses to these cases. Part II explores Congress's power to give meaning to constitutional rights under the enforcement provisions of the Civil War Amendments. Part III concludes that, as a matter of precedent and constitutional structure, Congress's power under the enforcement provision of the Fourteenth Amendment is very broad and that the RFRA, the FOCA, and the RJA are well within that power.

${ }^{24}$ See, e.g., 138 CONG. REC. S9028 (daily ed. June 25, 1992) (statement of Sen. Cranston) (declaring that the FOCA is within Congress's $\S 5$ power); 138 CoNG. REC. S9185 (daily ed. June 30, 1992) (statement of Sen. Adams) (same); 138 CoNG. REC. E685 (daily ed. Mar. 16, 1992) (statement of Rep. Edwards) (same); 136 CoNG. REC. H9008 (daily ed. Oct. 5, 1990) (statement of Rep. Schroeder) (declaring that the RJA takes up a challenge from the Supreme Court to protect against racial disparities in capital sentencing under Congress's $\$ 5$ power); 135 CoNG. REC. H6954 (daily ed. Oct. 11, 1989) (statement of Rep. Ridge) (declaring that legislation to exclude illegal aliens from the census population figures is within Congress's $\$ 5$ power); 133 CoNG. REC. S931 (daily ed. Jan. 20, 1987) (statement of Sen. Hatch) (declaring that legislation to prohibit lower federal courts from using busing to integrate public schools is within Congress's $\$ 5$ power); 131 CoNG. REC. S130-31 (daily ed. Jan. 3, 1985) (statement of Sen. Hatch) (same).

25 See supra notes 23-24.

${ }^{26}$ Some members of Congress have argued that legislation is unconstitutional because it exceeds Congress's $\$ 5$ power. See, e.g., 136 CoNG. REc. E1485-86 (daily ed. May 10, 1990) (statement of Rep. Dannemeyer) (referring to the FOCA as the "Freedom 'to Kill' Act" and opposing the measure as beyond Congress's § 5 power); 136 CONG. REC. H261 (daily ed. Feb. 6, 1990) (statement of Rep. Campbell of California) (opposing national voter registration legislation as beyond Congress's $§ 5$ power). At least one of these members has, at the same time, favored different legislation based on the $\S 5$ power. See Religious Freedom Restoration Act of 1990: Hearings on H.R. 5377 Before the Subcomm. On Civil and Constitutional Rights of the House Comm. on the Judiciary, 101st Cong., 2d Sess. 8-10 (1990) [hereinafter 1990 -RFRA Hearings] (statement of Rep. Dannemeyer) (advocating the RFRA). 


\section{THE COURT RESTRICTS THREE RIGHTS}

\section{A. Religious Freedom}

\section{The Court Discards the Sherbert Test}

On April 17, 1990, the Supreme Court decided Employment Division v. Smith, ${ }^{27}$ an historic decision involving the First Amendment right to the free exercise of religion. In Smith, the Court held that the government may, without demonstrating a compelling governmental interest, prohibit religious conduct by enacting generally applicable, religion-neutral laws. ${ }^{28}$ More specifically, the Court held that Oregon could constitutionally withhold unemployment benefits from Alfred Smith and Galen Black after they lost their jobs for using peyote in violation of Oregon drug laws, even though the use was part of a religious ceremony. ${ }^{29}$

Smith substantially revised the prevailing interpretation of the second clause of the First Amendment's declaration that "Congress shall make no law respecting an establishment of religion, or prohibiting the Free Exercise thereof. ${ }^{n 0}$ Previously, the Court had generally applied a standard known as the "Sherbert test."

27494 U.S. 872 (1990).

28 See it. at 886 n.3.

${ }^{29}$ See id. at 890 . For in-depth analyses of Smith, see James D. Gordon, III, Free Exercise on the Mountaintop, 79 CAL. L. REV. 91 (1991); Douglas Laycock, The Remnants of Free Exercise, 1990 SUP. CT. REV. 1; William P. Marshall, In Defense of Smith and Free Exercise Revisionism, 58 U. CHI. L. REV. 308 (1991); Michael W. McConnell, Free Exercise Revisionism and the Smith Decision, 57 U. CHI. L. REV. 1109 (1990); Roald Mykkeltvedt, Employment Division v. Smith: Creating Anxiely by Relieving Tension, 58 TENN. L. REV. 603 (1991); Richard K. Sherwin, Rhetorical Pluralism and the Discourse Ideal: Countering Division of Employment v. Smith, A Parable of Pagans, Politics and Majoritarian Rule, 85 Nw. U. L. REV. 388 (1991); Danielle A. Hess, Note, The Undoing of Mandatory Free Exercise Accommodation-Employment Division, Department of Human Resources v. Smith, 66 WASH. L. REV. 587 (1990); Kenneth Marin, Note, Employment Division v. Smith: The Supreme Court Alters the State of Free Exercise Doctrine, 40 AM. U. L. REV. 1431 (1991).

${ }^{30}$ U.S. CONST, amend. I. Since 1940, the religion clauses of the First Amendment have applied not just to Congress, but to the states as well. See Cantwell v. Connecticut, 310 U.S. 296 (1940) (holding unconstitutional the application to Jehovah's Witnesses of a state statute which prohibited the public solicitation of contributions without approval from state authorities). Cantwell applied the First Amendment to the states by incorporating the First Amendment into the Due Process Clause of the Fourteenth Amendment, see id. at 303-07, which prohibits the states from depriving any person of "liberty" without "due process of law." U.S. CONST. amend. XIV.

31 See, e.g., Smith, 494 U.S. at 883 (citing Sherbert v. Verner, 374 U.S. 398, 403 (1963), the first case in which a majority of the Court held that a state may place 
That test required the government to demonstrate a compelling state interest when it infringed upon a person's religious conduct. $^{32}$ The Smith Court, however, discarded the Sherbert test, broadly holding that "generally applicable, religion-neutral laws that have the effect of burdening a particular religious practice need not be justified by a compelling governmental interest. ${ }^{\text {33 }}$

The result in Smith was particularly surprising because the Sherbert test originated in a case involving unemployment benefitsthe same governmental interest at stake in Smith. In Sherbert $v$. Verner, ${ }^{34}$ the Court held unconstitutional a state's denial of unemployment benefits to a Seventh-Day Adventist who refused to accept employment requiring her to work on Saturday, her sabbath. ${ }^{35}$ The Court found that the denial of benefits substantially burdened the appellant's free exercise of religion ${ }^{36}$ and that the state's interest in avoiding fraudulent claims was not compelling. ${ }^{37}$ The Court further held that, even if such an interest were compelling, the state must show that denying the benefits was the least restrictive means of achieving that interest. ${ }^{38}$

Before Smith, the Court had twice reaffirmed the Sherbert test in the context of unemployment benefits. In Thomas $v$. Review Board, ${ }^{39}$ the Court held unconstitutional the denial of unemployment benefits to a Jehovah's Witness who quit his job in a machine company when he was transferred to a department that produced armaments. As in Sherbert, the Court found that the denial of benefits was a significant burden on the appellant's religious beliefs (which required pacifism), that the state had not established its interest in preventing widespread unemployment, and that the state

burdens on religious conduct only if it demonstrates a "compelling state interest in the regulation").

32 See infra text accompanying notes $34-50$. The first case to analyze religious conduct separately from religious belief was Reynolds v. United States, 98 U.S. 145 (1878). In Reynolds, the Court upheld a conviction for bigamy against a free exercise claim, rejecting the notion that bigamy is a religious belief and holding that bigamy is an "overt act" which the state could criminally prohibit. See id. at 162; Cantwell, 310 U.S. at 303-04 (reaffirming the distinction between religious conduct and religious belief and holding that belief receives absolute protection whereas conduct receives a lower level of protection).

${ }^{33}$ Smith, 494 U.S. at 886 n.3.

34374 U.S. 398 (1963).

${ }^{35} \mathrm{See}$ id. at 410 .

${ }^{36}$ See id. at 403 .

37 See id. at 407 .

${ }^{38}$ See id.

${ }^{39} 450$ U.S. 707 (1981). 
had not demonstrated that it had chosen the least restrictive means of achieving its interest. ${ }^{40}$ Similarly, in Hobbie $v$. Unemployment Appeals Commission, ${ }^{41}$ the Court invalidated Florida's denial of unemployment compensation to a Jehovah's Witness who refused to work on Saturdays. In Hobbie, the Court found that the state had burdened the appellant's religion and that the state had failed to articulate a compelling interest. ${ }^{42}$ Thus, prior to Smith, the Court had applied the Sherbert test in three cases involving a state's denial of unemployment benefits and, in all three cases, held the state's action unconstitutional.

In cases where the government has burdened religious practice by criminalizing conduct rather than by denying certain benefits, the Court has also applied the Sherbert test. For example, in United States $v . L e e,{ }^{43}$ an Amish employer sought, on behalf of himself and his employees, relief from the collection and payment of Social Security taxes because his faith prohibited participation in government welfare programs. The Court found that although the tax system burdened the Amish's free exercise rights, ${ }^{44}$ the burden was justified because the government had demonstrated a compelling interest in mandating contribution to the Social Security system. ${ }^{45}$ Similarly, in Gillette $v$. United States, ${ }^{46}$ the Court sustained the military selective service system against the claim that it violated the free exercise right by conscripting people who object to a particular war on religious grounds. In Gillette, the Court found that the "Government's interest in procuring the manpower" necessary to fight wars was compelling enough to override the burden on the appellant's religion. ${ }^{47}$ Finally, in Braunfeld $v$. Brown, ${ }^{48}$ the Court upheld Sunday-closing laws against the claim that they burdened the religious practices of persons whose religions compelled them to refrain from work on other days. In Braunfeld, the Court found that the state had a compelling interest in providing a uniform day of rest. ${ }^{49}$

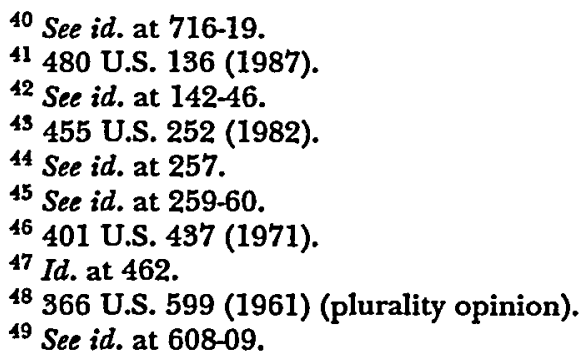


Thus, the Court has used the Sherbert test for over thirty years to weigh the importance of state and federal laws against the importance of religious conduct. In both the unemployment compensation context and the criminal context, the Court has employed the Sherbert test. It was no surprise, therefore, that when the litigants showed up to argue Smith, they assumed Sherbert would provide the standard of judgment and presented their arguments within the Sherbert framework. ${ }^{50}$ The Court's response was, however, unexpected.

Despite Sherbert, Thomas, and Hobbie, the Smith Court upheld Oregon's denial of unemployment benefits and held the Sherbert test inapplicable to "across-the-board criminal prohibition[s] on a particular form of conduct," such as those at issue in Lee, Gillette, and Braunfeld. ${ }^{51}$ The Court held that a strict scrutiny test like the Sherbert test is more appropriate to equal protection cases dealing with racial discrimination and to free speech cases than to free exercise cases. ${ }^{52}$ In the former fields, a strict scrutiny test produces the constitutional norms of equality of treatment and an unrestricted flow of information. In the free exercise field, however, the Court declared that the test would create a "constitutional anomaly" by producing a private right to ignore generally applicable laws. ${ }^{53}$ The Court viewed laws that expressly single out religious practices as subject to the Sherbert test, but held that "generally applicable, religion-neutral laws" stand on a different footing. ${ }^{54}$ In other words, the government may burden religious conduct as an incidental effect of an otherwise neutral scheme.

${ }^{50}$ See 1990 RFRA Hearings, supra note 26, at 42 (1990) (statement of Rev. Robert P. Dugan, Jr., Director, Office of Public Affairs, National Association of Evangelicals).

${ }^{51}$ Smith, 494 U.S. at 884-85. The Court distinguished another group of free exercise cases by declaring them to involve more constitutional infirmities than the violation of the free exercise right. The Court interpreted Cantwell v. Connecticut, 310 U.S. 296 (1940) (invalidating a state licensing system for the solicitation of religious and charitable contributions), as a free exercise plus free speech case. See Smith, 494 U.S. at 881. Similarly, the Court interpreted Wisconsin v. Yoder, 406 U.S. 205 (1972) (invalidating compulsory school attendance laws), and Pierce v. Society of Sisters, 268 U.S. 510 (1925) (same), as free exercise plus substantive due process parental rights cases. See Smith, 494 U.S. at 881 n.1. The Court concluded that the Oregon law did not involve such a "hybrid" situation, id. at 882 , and apparently believed that Cantwell, Pierce, and Yoder would have been decided differently had the free exercise claims in those cases stood alone. See id.

52 See id. at 885-86.

${ }^{53} \mathrm{Id}$. at 886.

${ }^{54}$ Id. at 886 n.3. 
Justice Scalia, writing for the Court, reasoned that to continue to apply the Sherbert test would be "courting anarchy" because a great many laws run afoul of religious conduct. ${ }^{55}$ To justify this conclusion the Court marched out a "parade of horribles," warning that compulsory military service laws, health and safety laws, compulsory vaccination laws, drug laws, traffic laws, welfare laws, child labor laws, animal cruelty laws, environmental protection laws, and racial discrimination laws would all be in danger if the test were to be applied to them. ${ }^{57}$

The Court declared that the political process affords ample protection to religious freedom. ${ }^{58}$ It cited a number of state statutes exempting the religious use of peyote from criminal laws and noted that to say that such an exemption is desirable is not to say that "the appropriate occasions for its creation can be discerned by the courts." ${ }^{.59}$ The Court recognized that leaving this accommodation to the political process might place minority religions at a disadvantage, but believed that this was an "unavoidable consequence of democratic government" preferable to the anarchy of allowing judges to weigh the importance of religious beliefs against the importance of laws. ${ }^{60}$

${ }^{55}$ See id. at 888-89.

${ }^{56} \mathrm{Id}$. at 889 n.5.

${ }^{57}$ See id. at 888-89. Another reason the Court cited for discarding the Sherbert test was that there were several free exercise cases in which the Court had not applied the Sherbert test at all. See Smith, 494 U.S. at 883-84. For this proposition, the Court cited Lyng v. Northwest Indian Cemetery Protective Ass'n, 485 U.S. 439 (1988) (upholding, without showing a compelling state interest, governmental logging and road construction activities on religious Native American lands); O'Lone v. Estate of Shabazz, 482 U.S. 342 (1987) (upholding, without showing a compelling state interest, a prison's refusal to excuse an inmate from work requirements in order to attend worship services); Bowen v. Roy, 476 U.S. 693, 701 (1986) (upholding, without showing a compelling state interest, the government's identification of people by social security number even though it violated a Native American religious tenet); Goldman v. Weinberger, 475 U.S. 503 (1986) (upholding, without showing a compelling state interest, military dress regulations forbidding the wearing of yarmulkes).

${ }^{58}$ See Smith, 494 U.S. at 890.

${ }^{59} I d$.

${ }^{60} \mathrm{Id}$. 


\section{Justice O'Connor Would Retain the Sherbert Test}

In a sharply worded opinion concurring in the judgment, Justice O'Connor criticized the majority's rejection of the Sherbert test and argued that the Court should retain the test. ${ }^{61}$ Justice O'Connor contended that the Sherbert test was both a workable and just means of resolving conflicts between government and religious liberty. Her reasoning sheds light on the motivations behind the RFRA.

In her opinion, Justice O'Connor asserted that the First Amendment does not distinguish between generally applicable laws and those directly targeting religious conduct. ${ }^{62}$ Justice O'Connor noted that Hobbie v. Unemployment Appeals Commission ${ }^{63}$ had rejected such an interpretation and she reasoned that if the protection of religious freedom is to have any vitality, it ought not to be reserved for instances in which the state enacts laws patently targeting religion. ${ }^{64}$ She quite sensibly declared that "few States would be so naive as to enact a law directly prohibiting or burdening a religious practice as such. ${ }^{n 65}$

Justice O'Connor also took issue with the Court's declaration that religious freedom from generally applicable laws is a constitutional anomaly. Rather, she averred, religious freedom is as much a constitutional norm as freedom from discrimination and freedom of speech. ${ }^{66}$ She added that the Court's "parade of horribles" demonstrates not that the Sherbert test results in anarchy, but that

61 See id. at 891-907 (O'Connor, J., concurring in the judgment).

62 See id. at 894 (O'Connor, J., concurring in the judgment).

63480 U.S. 136 (1987).

${ }^{64}$ See Smith, 494 U.S. at 894 (O'Connor, J., concurring in the judgment).

${ }^{65} \mathrm{Id}$. (O'Connor, J., concurring in the judgment). Additionally, Justice O'Connor responded to the Court's analysis of the so-called hybrid cases, see supra note 51, by noting that in Cantwell and Yoder the Court had explicitly based its holding on the free exercise claim. See id. at 896 (O'Connor, J., concurring in the judgment). Moreover, Justice $O$ 'Connor denied that the Court had rejected or declined to apply the Sherbert test in recent cases. See supra note 57. Rather, she suggested that in Roy and Lyng the Court expressly distinguished Sherbert on the ground that the government itself need not alter its internal affairs to comport with particular religious beliefs. See $i d$. at 900 (O'Connor, J., concurring in the judgment) (citing Bowen v. Roy, 476 U.S. 693, 699 (1986)). Justice O'Connor stated that Goldman and Shabazz were cases in which the Sherbert test did not apply because the Court's review of military and prison regulations is far more deferential than when the Court reviews burdens on civilians or the non-prisoner population. See id. at 900-01 (O'Connor, J., concurring in the judgment). Thus, she argued, the Court should not view those cases as controlling paradigm free exercise cases such as Smith. See id. at 901 (O'Connor, J., concurring in the judgment).

${ }^{66}$ See Smith, 494 U.S. at 901 (O'Connor, J., concurring in the judgment). 
the Court has been quite able to strike a sensible balance between religious liberty and governmental interests. ${ }^{67}$

Finally, Justice O'Connor refused to accept the majority's proposition that the oppression of minority religious practice is an unavoidable consequence of democracy. ${ }^{68}$ Rather, she claimed that the First Amendment was added to the Constitution precisely to protect religious minorities. Justice O'Connor closed her argument with a famous quote from Justice Jackson:

The very purpose of a Bill of Rights was to withdraw certain subjects from the vicissitudes of political controversy, to place them beyond the reach of majorities and officials and to establish them as legal principles to be applied by the courts. One's right to life, liberty, and property, to free speech, a free press, freedom of worship and assembly, and other fundamental rights may not be submitted to vote; they depend on the outcome of no elections. ${ }^{69}$

Paradoxically, the legislative movement to enact the RFRA is based both on Justice O'Connor's notion that the judiciary is quite capable of balancing the importance of religious conduct against state interests and on the majority's belief that religious freedom

$67 \mathrm{See} i d$. at 902 (O'Connor, J., concurring in the judgment); see also 1990 RFRA Hearings, supra note 26, at 54 (statement of John H. Buchanan, Jr., Chairman, People For The American Way Action Fund) ("[Justice Scalia's majority opinion listed] several types of government rules ... where the Court has found a compelling state interest ... . In so doing, we believe that Justice Scalia unwittingly proved the very point at issue here today: the system works!").

${ }^{68}$ See Smilh, 494 U.S. at $902-03$ (O'Connor, J., concurring in the judgment).

${ }^{69} \mathrm{Id}$. at 903 (O'Connor, J., concurring in the judgment) (quoting West Virginia Bd. of Educ. v. Barnette, 319 U.S. 624, 638 (1943)). In the last part of her opinion, Justice O'Connor applied the Sherbert test to the facts in Smith. She concluded that Oregon had demonstrated a compelling interest in stemming the drug trade and could therefore burden the Native American Church's use of peyote. See id. at 903-07 (O'Connor, J., concurring in the judgment). Justices Brennan, Blackmun, and Marshall joined Justice O'Connor's opinion insofar as it called for the retention of the Sherbert test, but they did not join the portion of her opinion that would have found that the state's interest was compelling. See id. at $891 \mathrm{n}$.*. Justice Blackmun's dissent examined the use of peyote in Oregon and found that its religious use did not pose a danger of furthering the drug trade. See id. at 911-19 (Blackmun, J., dissenting). He noted that the religious use of peyote might actually inhibit the drug trade because the Native American Church prohibits the use of alcohol and other drugs and even prohibits the use of peyote outside of its religious services. See id. at 914 (Blackmun, J., dissenting). Justice Blackmun pointed out that Oregon had only once prosecuted a person for the religious use of peyote. See id. at 911 n.3 (Blackmun, J., dissenting) (citing State v. Soto, 537 P.2d 142 (Or. 1975), cert. denied, 424 U.S. 955 (1976)). Thus, he concluded that the state's interest in stemming the drug trade by prohibiting the religious use of peyote was not compelling. See id. at 921 (Blackmun, $\mathrm{J}$., dissenting). 
can be protected through the political process. Whereas Smith deferred the protection of religious freedom to the legislature, the RFRA bounces the ball right back to the Court.

\section{Congress Responds to Smith}

The Religious Freedom Restoration Act is designed to counteract the Court's decision in Smith by reestablishing the Sherbert test. $^{70}$ Specifically, the RFRA would prohibit the state and federal governments from restricting a person's exercise of religion without demonstrating both a compelling governmental interest in the restriction and that the restriction is the least restrictive means of achieving the governmental objective. ${ }^{71}$ The bill also would provide a civil remedy and would authorize the recovery of attorneys' fees. ${ }^{72}$

Significantly, the bill guarantees application of the Sherbert test "in all cases where free exercise of religion is burdened."73 This

${ }^{70}$ See H.R. 2797, 102d Cong., 1st Sess. (1991). Representative Solarz and Senator Biden had introduced similar bills in the previous Congress. See H.R. 5377, 101st Cong., 2d Sess. (1990); S. 3254, 101st Cong., 2d Sess. (1990).

71 See H.R. 2797 \& $3(\mathrm{a})-(\mathrm{b})$.

72 See id. $\$ \S 3($ c), 4. H.R. 2797, like Senator Biden's bill in the previous Congress, applies its restrictions to any person "acting under color of law." $I d . \S 5(1) ; \mathrm{S} .3254$ $\S 4(1)$. If the Court's interpretation of a similar color of law provision in the civil rights field were applied to the Senate bill, a state actor would be acting under color of state law (and thus violating the RFRA) even if the actor were not acting pursuant to state law. See Monroe v. Pape, 365 U.S. 167, 183 (1961) (holding that a police officer who violated a person's constitutional rights but who also violated state law was nonetheless acting "under color of state law" for purposes of a Reconstruction-era civil rights statute, 42 U.S.C. $\$ 1983$ (1988)). Thus, the RFRA creates a cause of action against state actors in states that nominally give persons the same rights as the RFRA but that, in practice, do not protect those rights.

In the 102d Congress, the RFRA became bogged down in an abortion controversy. Abortion opponents charged that the bill would give an abortion right to women who claim a religious reason for seeking abortions. See 1992 RFRA Hearings, supra note 4, (statement of Mark Choptko, General Counsel, U.S. Catholic Conference at 8) (urging Congress to adopt an abortion neutrality provision); id. (statement of James Bopp, General Counsel, National Right to Life Committee at cover page) (arguing that the RFRA "must expressly exclude a right to abortion"); id. (statement of Professor Douglas Laycock at 16-17) (urging Congress to not carve out exceptions to the RFRA but to return the free exercise right to where it would have been without Smith); see also Larry Witham, Abortion Clouds Bill on Religion, WAsH. TIMES, Mar. 2, 1992, at A6. In response to this controversy, Representative Christopher Smith introduced the "Religious Freedom Act of 1991," a bill to reestablish the Sherbert test, but that prevents women from using the legislation to challenge abortion regulations. See H.R. 4040, 102d Cong., 1st Sess. § 3 (1991); see also 137 CONG. REC. E4186 (daily ed. Nov. 26, 1991) (statement of Rep. Smith).

${ }^{73}$ H.R. 2797 § 2(b) (emphasis added). 
wording makes the RFRA apply broadly. Prior to Smith, the Court did not apply the Sherbert test to all cases in which government burdened religious conduct but, starting in 1986, had carved out exceptions for military regulations, prison regulations, and internal government regulations. ${ }^{74}$ By explicitly applying itself to all cases in which the government burdens religion, the RFRA would return the law not to the status quo ante Smith but to the status quo ante 1986. This legislative approach eliminates the difficulty of having the courts determine which government actions are internal or similar to military or prison regulations. Under the RFRA, all government burdens on religious conduct would be subject to the Sherbert test. ${ }^{75}$

While it is impossible under Smith to completely withdraw free exercise rights from the majority's will (because even if enacted the RFRA would be subject to repeal or amendment), the RFRA will unquestionably withdraw free exercise rights from the vicissitudes of state legislatures. Moreover, repealing or amending laws that protect constitutional rights is difficult to do; once such laws are on the books, they tend to become highly respected components of our democracy. ${ }^{76}$ Enacting the RFRA would thus create a serious obstacle to efforts to restrict religious freedom.

There is some irony in retreating to the majoritarian process in order to protect individual freedom. However, the RFRA does not place control over individual rights in the hands of the majority on a case-by-case basis. Rather, by returning the free exercise right to its former status, the RFRA requires the judicial branch to apply the Sherbert test. In other words, the RFRA leaves religious exercise controversies "just where they would be under the Free Exercise Clause if Smith . . . had never happened. ${ }^{77}$

74 See supra note 57.

75 This makes sense if one views the cases addressing military, prison, and internal government regulations as having held those governmental interests to be compelling. Cf. Kristen L. Boyles, Note, Saving Sacred Sites: The 1989 Proposed Amendment to the American Indian Religious Freedom Act, 76 CORNELL L. REv. 1117, 1139 n.144 (1991) (contending that the "internal notion" is problematic).

${ }^{76}$ See Letter from Walter Dellinger, Professor of Law, Duke University School of Law, to Senator George J. Mitchell, Majority Leader, United States Senate 1 n.1 (Feb. 6, 1992) [hereinafter Letter from Professor Dellinger] ("The continued reverence for the Civil Rights Act of 1964 and the Voting Rights Act of 1965 demonstrates that a federal legislative solution to an important problem, once achieved, can become a permanent part of our national laws") (on file with author).

${ }^{77} 1992$ RFRA Hearings, supra note 4 (statement of Professor Douglas Laycock at 16). 


\section{B. The Right to Abortion}

\section{Webster and Casey}

If it can be said that the Supreme Court used an axe to pare the free exercise right, it might also be said that the Court has chipped away at the abortion right with a pen knife. Nonetheless, over the last five years, the Court has sedulously, if incoherently, cut back the abortion right. As it now stands, the abortion right is significantly less protective than when Roe v. Wade ${ }^{78}$ and Doe v. Bolton ${ }^{79}$ established the right in 1973.

The Fourteenth Amendment holding in Roe grew out of a line of cases holding that the right to due process of law, as it pertains to individual liberty, provides a fundamental right to control one's own body. ${ }^{80}$ Specifically, in Roe, the Court held that the due process clause of the Fourteenth Amendment ${ }^{81}$ prohibits the states from denying a woman the right to an abortion during the first two trimesters of a pregnancy. ${ }^{82}$ During the third trimester, when the fetus has reached viability, the state's interest in protecting potential life becomes compelling and the state may then proscribe abortion except when it would endanger the life or health of the mother. ${ }^{83}$

Since Roe, the states have attempted to regulate the abortion right in many ways. Most of these attempts have been unsuccessful:

The Court has ... invalidated laws requiring that women seeking abortions be given detailed descriptions of fetal development, informed of particular physical and psychological risks associated with abortion, and reminded of the availability of assistance from

${ }^{78} 410$ U.S. 113 (1973).

79410 U.S. 179 (1973).

${ }^{80}$ See, e.g., Eisenstadt v. Baird, 405 U.S. 438, 453 (1972) ("If the right of privacy means anything, it is the right of the individual, married or single, to be free from unwarranted government intrusion into matters so fundamentally affecting a person as the decision whether to bear or beget a child."); Griswold v. Connecticut, 381 U.S. 479 (1965) (holding that states cannot make the use of contraceptives by married couples a crime); Rochin v. California, 342 U.S. 165 (1952) (holding that for the state to procure evidence by stomach-pumping an individual violates the due process clause of the Fourteenth Amendment); Skinner v. Oklahoma, 316 U.S. 535 (1942) (holding unconstitutional a state law providing for the sterilization of persons convicted two or more times of certain felonies); see also LAURENCE H. TRIBE, AMERICAN CONSTITUTIONAL LAW 1337-41 (2d ed. 1987) (discussing the evolution of the right to bodily integrity).

81 "[N]or shall any State deprive any person of life, liberty, or property, without due process of law." U.S. CoNST. amend. XIV.

82 See Roe, 410 U.S. at 163.

${ }^{83}$ See id. at 163-64. 
the father or from social service agencies should the woman decide to give birth. Moreover, states cannot require that a woman wait for a statutorily fixed period after signing a consent form before the abortion procedure may be performed....

Blanket requirements of third-party consent to a woman's decision to have an abortion are unconstitutional even as applied only to non-therapeutic procedures, regardless of the woman's age. The Court has been unwilling to allow states to give either the pregnant woman's husband or her parents an absolute veto over an abortion that the states themselves would be powerless to forbid. ... Requirements of parental consent must provide for an alternative form of approval-a judicial "bypass"-for a minor who is sufficiently mature to make the decision herself, or who can demonstrate that an abortion would be in her best interests. ${ }^{84}$

For many years, this was the law governing abortion. Although the Court upheld some restrictions on the abortion right during the 1970 s and 1980s, the Court's treatment of the right remained essentially static for most of this period. ${ }^{85}$

Then, in 1989, the Supreme Court decided Webster v. Reproductive Health Services, ${ }^{86}$ a case involving a challenge to a Missouri law regulating abortions. Webster signalled a major turning point in the Court's abortion jurisprudence by undermining the strict scrutiny standard Roe had established as the constitutional measure of restrictions on the abortion right. ${ }^{87}$ In this sense, Webster resembles Smith.

In contrast to Smith, however, the Webster Court could not muster a majority to determine a standard to replace the strict scrutiny standard. ${ }^{88}$ The Missouri statute contained several different provisions, one of which appeared to require viability testing for all abortions performed during or after the twentieth week of pregnancy. ${ }^{89}$ The viability-testing provision offered the most direct challenge to Roe because the Court had previously held

84 TRIBE, supra note 80 , at $1343-44$ (citations omitted).

${ }^{85}$ See David J. Zampa, Note, The Supreme Court's Abortion Jurisprudence: Will the Supreme Court Pass the "Albatross" Back to the States?, 65 NOTRE DAME L. REV. 731, 763 (1990) (arguing that Webster marks the end of an era of relative consistency in abortion jurisprudence). This note offers an excellent summary of the Court's abortion jurisprudence from Roe through Webster.

${ }^{86} 492$ U.S. 490 (1989).

${ }^{87}$ See Zampa, supra note 85, at 763-64.

${ }^{88}$ In Smith the Court lowered the standard to a rational basis test for most state restrictions of the free exercise right. See supra text accompanying notes 51-54.

${ }^{89}$ See Webster, 492 U.S. at 501. 
that Roe prohibits the states from participating in the viability determination. ${ }^{90}$ In interpreting the viability-testing provision, Chief Justice Rehnquist, joined by Justices White and Kennedy, disparaged the Roe trimester approach and adopted a "modified rationality standard" 91 which would simply require that the abortion restriction "permissibly further[] the State's interest in protecting potential human life." 92 Nonetheless, the plurality believed that while the Missouri statute challenged the Roe framework, the statute did not challenge Roe itself because it did not seek to ban pre-viability abortions. ${ }^{93}$ The plurality thus sought to modify but not overrule Roe. ${ }^{94}$

Justice O'Connor concurred in the plurality's judgment but thought that the Missouri statute did not provide the opportunity to challenge the trimester framework of Roe. ${ }^{95}$ She nonetheless offered her own standard to measure restrictions on the right to abortion: she would hold a restriction unconstitutional if it imposed an "undue burden on a woman's abortion decision." Justice Scalia also concurred in the plurality's judgment, arguing that the Court should simply overturn Roe. ${ }^{97}$ Thus, five members of the Court voted to uphold a law that imposed a previously prohibited restriction on the abortion right. More importantly, those five justices also voted to weaken the compelling state interest test-though they could not agree on what should replace the test. ${ }^{98}$

${ }^{90}$ See Colautti v. Franklin, 439 U.S. 379, 390 (1979).

91 Zampa, supra note 85 , at 772.

92 Webster, 492 U.S. at 519-20.

93 See id. at 521 (Rehnquist, C.J.)

94 See id. (Rehnquist, C.J.)

${ }^{95} \mathrm{See} i d$. at 525 (O'Connor, J., concurring in part and concurring in the judgment).

${ }^{96} \mathrm{Id}$. at 530 (O'Connor, J., concurring in part and concurring in the judgment).

${ }^{97}$ See id. at 536-37 (Scalia, J., concurring in part and concurring in the judgment).

98 Justice Blackmun, joined by Justices Brennan and Marshall, lodged a strong dissent. Justice Blackmun concurred only in the Court's holding that the respondent's challenge to one section of the Missouri statute was moot. See id. at $541 \mathrm{n} .1$ (Blackmun, J., concurring in part and dissenting in part). Justice Blackmun, who wrote the majority opinion in Roe, argued passionately for the retention of the Roe framework and for the strict scrutiny of restrictions on the abortion right. See generally id. at 537-60 (Blackmun, J., concurring in part and dissenting in part). Justice Blackmun concluded that "[f]or today, the women of this Nation still retain the liberty to control their destinies." But, he noted, "the signs are evident and very ominous, and a chill wind blows." Id. at 560 (Blackmun, J., concurring in part and dissenting in part). Justice Stevens also concurred in part and dissented in part. He agreed with the Court on the mootness issue but, like Justice Blackmun, would have held the rest of the statute unconstitutional. See id. at 560 (Stevens, J., concurring in 
The next abortion rights case did little to resolve the confusion. Pennsylvania accepted the Court's "open invitation"99 to restrict the abortion right and passed a law regulating abortion in a number of ways. The Supreme Court considered the Pennsylvania statute in Planned Parenthood v. Casey. ${ }^{100}$ The most notable sections of the statute require that, at least twenty-four hours before the abortion is performed, a woman seeking an abortion be informed that she may review "printed materials which describe the unborn child" and have access to a list of agencies that offer alternatives to abortion; that a married woman seeking an abortion sign a statement indicating that she has notified her husband of her intended abortion; and that a minor seeking an abortion obtain the informed consent of one of her parents or the permission of a judge. ${ }^{101}$ Only women in a "medical emergency" may gain exemption from these provisions. ${ }^{102}$

By the time the challenge to this law reached the Supreme Court, President Bush, an opponent of abortion rights, ${ }^{103}$ had replaced two of the dissenters in Webster, Justices Brennan and Marshall, with two new appointees, Justices Souter and Thomas. Thus, many people expected the Court to overrule Roe outright. ${ }^{104}$

In an unexpected decision, however, the Casey Court voted to uphold the essential holding of Roe protecting a woman's right to have an abortion before fetal viability. Justices Kennedy, Souter, and O'Connor delivered a joint opinion that praised the Roe trimester framework. However, the joint opinion applied Justice O'Connor's undue burden standard, leading to the invalidation of only the spousal notification provision. In separate opinions,

part and dissenting in part). Justice Stevens was especially concerned that the Missouri law would interfere with the right to use contraceptives such as the IUD and the morning-after pill. See id. at 563 (Stevens, J., concurring in part and dissenting in part).

99137 CoNG. REC. S641 (daily ed. Jan. 14, 1991) (statement of Sen. Cranston); see also supra text accompanying note 14 .

${ }_{100} 112$ S. Ct. 2791 (1992).

101 See id. at 2833-38 (O'Connor, Kennedy, and Souter, JJ.).

102 See id.

${ }^{103}$ See Bar Group Votes To Fight Restrictions On Abortion, N.Y. TIMES, Aug. 12, 1992 , at Al4 ("President Bush opposes abortion"). But see Andrew Rosenthal, Bush, Asked in Personal Context, Takes a Softer Stand on Abortion, N.Y. TIMES, Aug. 12, 1992, at A1 (reporting that President Bush does not oppose abortion rights for members of his own family).

${ }^{104}$ See A! Kamen, Center-Right Coalition Asserts Itself, WASH. POST, June 30, 1992, at A1. 
Justices Blackmun and Stevens provided the fourth and fifth votes to uphold the Roe framework and to strike the spousal notification provision. ${ }^{105}$ Justices Blackmun and Stevens disagreed, however, with the joint opinion's adoption of the undue burden test. They advocated the strict scrutiny standard that Roe originally established. ${ }^{106}$

While the celebrated result of Casey is that the Court declined to overturn Roe, the Court continued to whittle away at the abortion right in Casey. Applying the undue burden standard, the Court upheld several provisions designed to discourage women from exercising their constitutional right to abortion. By a seven to two margin, the Court upheld the twenty-four hour waiting period during which Pennsylvania encourages women seeking abortions to review materials describing the fetus as "an unborn child," irrespective of their stage of pregnancy. ${ }^{107}$ By the same margin, the Court upheld the parental consent requirement-a provision that is certain to discourage the exercise of the abortion right. ${ }^{108}$

Most importantly, the abortion right itself remains at risk. From Webster to Casey the number of Justices seeking an intermediate

105 See Casey, 112 S. Ct. at 2838-43 (Stevens, J., concurring in part and dissenting in part); $i d$. at 2843-55 (Blackmun, J., concurring in part, concurring in the judgment in part, and dissenting in part).

${ }^{106}$ See id. at 2841 (Stevens, J., concurring in part and dissenting in part); id. at 2849 (Blackmun, J., concurring in part, concurring in the judgment in part, and dissenting in part). Thus, despite reports to the contrary, see Linda Greenhouse, High Court Begins Today With Focus on New Coalition, N.Y. TIMEs, Oct. 5, 1991 at A19 (reporting that in Casey "the Court" adopted the undue burden standard); Linda Greenhouse, High Court, 54, Affirms Right to Abortion But Allows Most of Pennsylvania's Limits, N.Y. TIMES, June 30, 1991 at A1 (stating that in Casey "the Court said that four sections of Pennsylvania's law did not impose an undue burden on the right to abortion"), the Court did not adopt the undue burden standard-only three Justices did so.

Chief Justice Rehnquist and Justices White, Scalia, and Thomas concurred in the Court's judgment insofar as it upheld Pennsylvania's abortion regulations and dissented insofar as it struck the husband notification provision and certain other provisions. See Casey, 112 S. Ct. at 2855-73 (Rehnquist, C.J., concurring in the judgment in part and dissenting in part); $i d$. at 2873-85 (Scalia, J., concurring in the judgment in part and dissenting in part). All four dissenters advocated overruling Roe and adopting a rational basis standard. See id. at 2855, 2867 (Rehnquist, C.J., concurring in the judgment in part and dissenting in part).

10718 PA. Cons. STAT. ANN. § 3205(a)(2)(i) (1990).

108 Minors seeking abortions who are required to either consult a parent or seek permission from a judge often opt to forgo the abortion. See Hodgson v. Minnesota, 110 S. Ct. 2926, 2953-54 (1990) (Marshall, J., dissenting) (citing Torres et al., Telling Parents: Clinic Policies and Adolescents' Use of Family Planning and Abortion Services, 12 FAMILY PLAN. PERSP. 284, 289-91 (1980)). 
("undue burden") standard increased from one to three while the number seeking a strict scrutiny standard decreased from four to two. The Roe framework survived by only a five to four margin; Justice Blackmun pointedly reminds us: "I am 83 years old. I cannot remain on this Court forever. ${ }^{\text {109 }}$

\section{Congress Responds to Webster and Casey}

The Freedom of Choice Act (FOCA) ${ }^{110}$ would counteract the Court's holdings in Webster and Casey by prohibiting the states from restricting the freedom of a woman to choose whether or not to terminate a pregnancy before fetal viability. ${ }^{111}$ Under the FOCA, the states may restrict the abortion right after the point of viability unless the abortion is necessary to preserve the life or health of the woman. ${ }^{112}$ In case these requirements leave any ambiguity, the FOCA states that it is the purpose of the bill to "achieve the same limitations as provided, as a constitutional matter, under the strict scrutiny standard of review enunciated in Roe v. Wade and applied in subsequent cases from 1973 to $1988 .{ }^{\text {"113 }}$ Moreover, the FOCA prohibits the states from imposing requirements on the performance of abortions unless the requirements are necessary to protect the health of the woman. ${ }^{114}$

The FOCA makes two concessions to its goal of protecting the abortion right. First, it does not apply to issues of public funding for abortions. ${ }^{115}$ Second, it does not prevent the states from requiring the consent of a parent, guardian, or other responsible adult before a minor may obtain an abortion. ${ }^{116}$

In addition, the FOCA sets forth a number of findings. According to the bill, Congress finds that recent Supreme Court decisions on abortion have, inter alia, resulted in physical harm to women, burdened interstate commerce by forcing people to travel among the states, interfered with the freedom to travel, burdened the medical and economic resources of states that do not restrict the abortion right, and discriminated among people based on their

${ }^{109}$ Casey, 112 S. Ct at 2854 (Blackmun, J., concurring in part, concurring in the judgment in part, and dissenting in part).

${ }^{110}$ S. 25, Version 2, 102d Cong., 2d Sess. (1992).

111 See id. \$ 3(a).

112 See id.

113 Id. § 2(b).

${ }^{114}$ See id. § 3(a)(3).

115 See id. § 3(b)(2).

116 See id. § 3(b)(3). 
ability to travel (causing disproportionate harm to racial and ethnic minorities who are generally less able to afford travel). ${ }^{117}$ The FOCA explicitly states its reliance on Congress's section 5 power (and on the commerce power) ${ }^{118}$ and declares that "[a]lthough Congress may not by legislation create constitutional rights, it may, where authorized by its enumerated powers and not prohibited by a constitutional provision, enact legislation to create and secure statutory rights in areas of legitimate national concern." ${ }^{\text {119 }}$

\section{Equal Protection: Racial Disparities in Capital Sentencing}

\section{McCleskey v. Kemp $p^{120}$}

Warren McCleskey was an African-American man convicted in Georgia of two counts of armed robbery and one count of murder. He participated in a furniture store robbery in which a EuropeanAmerican police officer was shot. McCleskey claimed that he was not the person who shot the officer. But based on evidence linking the homicide bullets with the gun McCleskey was said to have carried at the robbery and on testimony that McCleskey admitted to the crime, the jury found McCleskey guilty of murder. Subsequently, he was sentenced to death. ${ }^{121}$

After an involved journey through state and federal courts, McCleskey filed a writ of habeas corpus in federal court. $\mathrm{He}$ claimed that Georgia administered its capital sentencing process in a racially discriminatory manner and thus violated both the Eighth Amendment ${ }^{122}$ and the Equal Protection Clause of the Fourteenth Amendment. ${ }^{123}$ At the heart of McCleskey's claim was a "sophisticated" statistical study demonstrating that murderers who were of African descent were more likely to receive the death sentence than murderers who were of European descent. ${ }^{124}$ The study also showed that those who murder persons of African descent were less

117 See id. § 2.

${ }^{118}$ See id. § 2(a)(4).

${ }^{119} I d . \S 2(\mathrm{a})(3)$.

120481 U.S. 279 (1987).

121 See id. at 283-85.

122 "Excessive bail shall not be required, nor excessive fines imposed, nor cruel and unusual punishments inflicted." U.S. CONST. amend. VIII.

123 "No State shall ... deny to any person within its jurisdiction the equal protection of the laws." Id. amend. XIV, $\$ 1$.

${ }^{124}$ McCleskey, 481 U.S. at 286. 
likely to receive the death sentence than those who murder persons of European descent. ${ }^{125}$

The Baldus study, as it is known, examined more than 2000 murder cases that occurred in Georgia in the 1970s. ${ }^{126}$ The Supreme Court summarized the results of the study as follows:

[T] he death penalty was assessed in $22 \%$ of the cases involving black defendants and white victims; $8 \%$ of the cases involving white defendants and white victims; $1 \%$ of the cases involving black defendants and black victims; and $3 \%$ of the cases involving white defendants and black victims.

Similarly, Baldus found that prosecutors sought the death penalty in $70 \%$ of the cases involving black defendants and white victims; $32 \%$ of the cases involving white defendants and white victims; $15 \%$ of the cases involving black defendants and black victims; and $19 \%$ of the cases involving white defendants and black victims. ${ }^{127}$

In addressing the Eighth Amendment claim, the district court concluded that the statistics did not demonstrate a prima facie case that the state imposed the death penalty on McCleskey because of his race "or because of any Eighth Amendment concern." 128 With respect to the Fourteenth Amendment claim, the district court concluded the Baldus study was flawed in a number of respects and thus failed to support McCleskey's claim. ${ }^{129}$

The Eleventh Circuit assumed, without deciding, that the Baldus study was sufficiently valid to show that "the factors of race of the victim and defendant were at work in Fulton County," where McCleskey was tried. ${ }^{130}$ Nonetheless, the court of appeals held that in order to invalidate a capital sentencing system on equal protection grounds without directly demonstrating a discriminatory intent, proof of a disparate impact must be so great that it compels the conclusion that the system is "unprincipled, irrational, arbitrary and capricious." ${ }^{131}$ The court of appeals therefore affirmed the district court's denial of the writ of habeas corpus.

125 See id.

126 See id.

127 Id. at $286-87$.

${ }^{128}$ McCleskey v. Zant, 580 F. Supp. 338, 379 (N.D. Ga. 1984), affd in part and rev'd in part sub nom. McCleskey v. Kemp, 753 F.2d 877 (11th Cir. 1985) (en banc), affd, 481 U.S. 279 (1987).

129 See McCleskey, 481 U.S. at 372.

${ }^{130}$ McCleskey, 753 F.2d at 895, affd, 481 U.S. 279 (1987).

${ }^{131} I d$. at 892. 
The Supreme Court heard the case and, like the court of appeals, assumed the validity of the Baldus study (although it noted that the study showed only a risk that the race factor was dispositive). ${ }^{132}$ The Court affirmed the court of appeal's decision on both the Eighth and Fourteenth Amendment claims. Justice Powell, writing for the Court, offered a number of reasons for the holding.

As to the equal protection claim, Justice Powell noted that when statistics are offered to demonstrate a constitutional violation, they must demonstrate a "stark' pattern to be accepted as the sole proof of discriminatory intent. ${ }^{\text {133 }}$ Although this tough standard is not required in cases alleging discrimination in jury selection or in cases alleging employment discrimination in violation of Title VII of the Civil Rights Act of 1964, Justice Powell distinguished those cases from McCleskey's claim. ${ }^{134}$ In the former, according to the Court, there were fewer possible variables relevant to the challenged decision. ${ }^{135}$ By contrast, the Court averred, in capital sentencing the Constitution requires "consideration of innumerable factors that vary according to the characteristics of the individual defendant and the facts of the particular capital offense."136 Moreover, the Court declared, in the jury selection and employment discrimination cases, the decision maker is given an opportunity to explain the challenged decision whereas jurors cannot be so questioned. ${ }^{137}$

The Court also noted that the enforcement of murder laws is one of "society's most basic tasks" 138 and that it would require "exceptionally clear proof" before it would invalidate capital sentences as violative of the Fourteenth Amendment. ${ }^{139}$ Finally, the Court rejected the notion that the Baldus study demonstrated a discriminatory purpose behind Georgia's capital sentences. Such a purpose could be proven, according to the Court, only by showing that the state maintained the death penalty statute because of an anticipated discriminatory effect. ${ }^{140}$

132 See McCleskey, 481 U.S. at 291 n.7.

${ }^{133}$ Id. at 293 (quoting Village of Arlington Heights v. Metropolitan Hous. Dev. Corp., 429 U.S. 252, 266 (1977)).

${ }^{134} \mathrm{See}$ id. at 294-97.

135 See id. at 295.

136 Id. at 294.

137 See id. at 296.

${ }^{138}$ Id. at 297 (quoting Gregg v. Georgia, 428 U.S. 153, 226 (1976) (White, J., concurring)).

${ }^{139}$ Id. at 297.

${ }^{140}$ See id. at 297-98. The Court declared that, "[a]t most, the Baldus study indicates a discrepancy that appears to correlate with race" but that "[a]pparent 


\section{Congress Responds to McCleskey}

The Racial Justice Act (RJA) ${ }^{141}$ would counteract McCleskey by prohibiting the state or federal governments from imposing or executing sentences of death in a racially discriminatory pattern. ${ }^{142}$ The RJA begins by declaring that Congress's section 5 power not only enables it to enact the RJA, but "calls upon Congress to enforce the Constitution's promise of equality under the law."143 Moreover, the RJA declares, equality under the law "is tested most profoundly by whether a legal system tolerates race playing a role in the determination of whether and when to administer the ultimate penalty of death. ${ }^{\text {"144 }}$ The bill recognizes

disparities in sentencing are an inevitable part of our criminal justice system." Id. at 312 (emphasis added); cf. Employment Div. v. Smith, 494 U.S. 872, 890 (1990) (declaring that placing minority religions at the mercy of a majoritarian process is the "unavoidable consequence of democratic government") (emphasis added). As to the Eighth Amendment claim in McCleskey, the Court concluded that existing Supreme Court decisions adequately safeguard against the abuse of the death penalty. See McCleskey, 481 U.S. at 303. Justices Brennan, Marshall, Blackmun, and Stevens dissented. Justice Brennan argued that the Baldus study demonstrated a risk of irrationality in sentencing that violated the Eighth Amendment. See id. at 320-21 (Brennan, J., dissenting). In a separate dissent, Justice Blackmun argued that the Baldus study demonstrated a clear violation of the Fourteenth Amendment's Equal Protection Clause. See id. at 361 (Blackmun, J., dissenting). In a third dissent, Justice Stevens noted that invalidation of McCleskey's sentence based on the Baldus study would not have invalidated all of Georgia's death sentences, but only those which, like McCleskey's, fell in the range of the study where race became a statistically significant factor. According to Stevens, death sentences for extremely serious crimes would not have been affected had the Court invalidated McCleskey's sentence based on the Baldus study. See id. at 367 (Stevens, J., dissenting).

On September 25, 1991, Georgia executed McCleskey. See Peter Applebome, Georgia Inmate Is Executed After 'Chaotic' Legal Move, N.Y. TIMES, Sept. 26, 1991, at A18. The execution remained uncertain right up until the end because the Supreme Court again considered the case when two jurors claimed that information improperly withheld at the trial affected their decision and that they no longer favored the sentence:

At 2:17 A.M. Mr. McCleskey was into the electric chair, only to be taken away three minutes later when officials learned the High Court was still pondering a stay.

He was placed back in the chair at 2:53 A.M. under the assumption that no news from the Court meant the execution was still on. Word that the Court had denied a stay came just as the execution was ready to begin at 3:04.

Id. Prison officials attached the electrodes to McCleskey's head and he was read a final prayer. At 3:13 Warren McCleskey was pronounced dead. See id.

141 S. 1249, 102d Cong., 1st Sess. (1991).

142 See id. \$ 3(a).

143 Id. § 2(1).

${ }^{144}$ Id. $\$ 2(2)$. 
the Supreme Court's reluctance to remedy such disparities without proof that a judge, prosecutor, or jury acted with a discriminatory intent and finds that Congress is the institutionally appropriate branch to "take system-wide, preventive measures" under its section 5 power. ${ }^{145}$ This power, the RJA exclaims, enables Congress to prevent practices and patterns that "entail an intolerable danger that persons of different races would be treated differently." 146

The RJA specifies that ordinary statistical proof would be sufficient to demonstrate a violative pattern and that it would not be necessary to demonstrate a discriminatory purpose in order to take advantage of the Act. ${ }^{147}$ Statistical evidence of a racial disparity in either the race of defendants or victims would establish a prima facie case of discrimination in violation of the Equal Protection Clause. ${ }^{148}$ To rebut this prima facie case, the government would have to show by clear and convincing evidence that identifiable and pertinent nonracial factors persuasively explain the racial disparities. ${ }^{149}$

The RJA would ensure the existence of information necessary for its implementation. It would require every federal agency or state that provides for capital punishment to establish a data collection system. ${ }^{150}$ Each system would be required to maintain standard forms containing information about the race, sex, age, and national origin of the defendant and list significant aspects of the case such as mitigating or aggravating factors. ${ }^{151}$ State prosecutors would be required to fill out the standard form for every capital case and transmit the form to the agency. ${ }^{152}$ Each system would be required to maintain an adequate index and be available to the public and to any person charged with a capital offense. ${ }^{153}$

As with the RFRA and the FOCA, enactment of the RJA would create a statutory right to enforce a constitutional right. As such, the RJA would always be subject to repeal or amendment. But as already noted, federal laws enforcing constitutional rights tend to become enshrined in our democracy. As Professor Walter Dellinger

\footnotetext{
${ }^{145} I d . \S 2(7)$.

${ }^{146} I d$.

147 See id. § 3(a).

148 See id.

${ }^{149}$ See id.

${ }^{150}$ See id.

151 See id.

152 See id.

${ }^{153}$ See id.
} 
points out, it is hard to imagine Congress tampering with the Civil Rights Act of 1964 or the Voting Rights Act of 1965..$^{154}$ This argument has special force as applied to the RJA because of the extreme repugnance of executing people based on their race and the close relationship such executions bear to the history of the Civil War Amendments. ${ }^{155}$

\section{CONGRESS'S POWER TO ENFORCE AND EXPAND CONSTITUTIONAL RIGHTS}

\section{A. Historical Background of Congressional Power}

The congressional efforts to overcome Smith, Webster, Casey and McCleskey raise the question of whether Congress has the power to prohibit conduct which the Court has said does not violate the Constitution. The view that the legislature should independently determine the constitutionality of legislation comports with the Madisonian vision of three coequal branches of government, each "charged with protecting the Constitution in its own deliberations." ${ }^{156}$ In fact, the "prevailing view of those serving in early Congresses was that Congress, as an independent branch of government, had both an independent authority and duty to decide constitutional questions."157

Several of our nation's early leaders shared Madison's conviction that the three branches of government are coequal. For example, in a letter to Abigail Adams defending his remission of punishments under the Alien and Sedition Acts, Thomas Jefferson asserted the following:

You seem to think it devolved on the judges to decide on the validity of the sedition law. But nothing in the Constitution has

154 See Letter from Professor Dellinger, supra note 76.

155 See ERIC FONER, A SHORT HISTORY OF RECONSTRUCIION, 1863-1877, at 184-98 (1990) (contending that the Civil War Amendments and accompanying enforcement statutes were designed to quell the Ku Klux Klan's murderous campaign against African-Americans and their defenders in the Reconstruction South).

${ }^{156}$ Stephen F. Ross, Legislative Enforcement of Equal Protection, 72 MINN. L. REv. 311,313 (1987) (citing DONALD G. MORGAN, CONGRESS AND THE CONSTITUTION 47-48 (1966)). To be sure, Madison thought that "in the ordinary course of Government, .. . the exposition of the laws and Constitution devolves upon the Judiciary." Id. at 313 n.10 (quoting 1 ANNALS OF CoNG. 500 (Joseph Gales ed., 1789)). Yet, as a member of the House of Representatives, Madison reminded his colleagues of their duty "so far as it depends upon us, to take care that the powers of the Constitution be preserved." Id.

${ }^{157}$ Id. (citing DONALD G. MORGAN, CONGRESS AND THE CONSTIIUTION 47 (1966)). 
given them a right to decide for the Executive, more than to the Executive to decide for them. Both magistrates are equally independent in the sphere of action assigned to them. The judges, believing the law constitutional, had a right to pass a sentence of fine and imprisonment; because the power was placed in their hands by the Constitution. But the executive, believing the law to be unconstitutional, were bound to remit the execution of it; because that power has been confided to them by the Constitution. That instrument meant that its co-ordinate branches should be checks on each other. ${ }^{158}$

Andrew Jackson declared an even stronger view in vetoing a bill to recharter the Bank of the United States:

The Congress, the Executive, and the Court must each for itself be guided by its own opinion of the Constitution.... The opinion of the judges has no more authority over Congress than the opinion of Congress has over the judges, and on that point the president is independent of both. The authority of the Supreme Court must not, therefore, be permitted to control the Congress or the Executive when acting in their legislative capacities, but to have only such influence as the force of their reasoning may deserve. ${ }^{159}$

In his 1858 campaign for the Senate, Abraham Lincoln argued that Congress should nullify the Court's decision in Dred Scott $v$. Sandford, ${ }^{160}$ which had declared the Missouri Compromise unconstitutional: "If I were in Congress, and a vote should come up on a question whether slavery should be prohibited in a new Territory, in spite of that Dred Scott Decision, I would vote that it should." 161 Lincoln repeated this theme in his 1861 inaugural address, stating that if government policy on "vital questions affecting the whole people is to be irrevocably fixed by decisions of

15811 WRITINGS OF THOMAS JEFFERSON 50-51 (A. Lipscomb ed., 1904), quoted in Paul Brest, Congress as Constitutional Decisionmaker and Its Power to Counter Judicial Doctrine, 21 GA. L. REV. 57, 67 (1986); see also Louis Fisher, Constitutional Interpretation by Members of Congress, 63 N.C. L. REv. 707, 711-12 (1985) (stating that Jefferson's constitutional theory envisioned the three branches as coequals with complete independence).

${ }_{159}$ Brest, supra note 158, at 67-68 (quoting 2 MESSAGES AND PAPERS OF THE PRESIDENT 576, 581-82 (J. Richardson ed., 1897)); see also, Fisher, supra note 158, at 712-14 (describing Jackson's theory of the three branches as having limits that Jefferson's theory does not recognize).

${ }^{160} 60$ U.S. (19 How.) 393 (1856).

161 Brest, supra note 158, at 77 (quoting A. LINCOLN: HIS SPEECHES AND WRITING 385, 396 (R. Basler ed., 1969)). 
the Supreme Court . . . the people will have ceased to be their own rulers.'"162

It was not until 1890 that members of Congress manifested a propensity for deferring constitutional questions to the judicial branch. In that year a leading proponent of an antitrust bill declared that the only way to determine the legislation's constitutionality was to refer it to the Supreme Court. ${ }^{163}$ By the time of the Great Depression, the view that Congress should refer constitutional questions to the Supreme Court was well established and it has remained so ever since. ${ }^{164}$

Despite general congressional deference to Supreme Court determinations of constitutionality, the Court has recognized that Congress has the power to give constitutional rights greater scope than the Court gives those rights absent congressional action. Matters concerning the Thirteenth, Fourteenth, and Fifteenth Amendments fall into this category. These provisions, known as the "Civil War Amendments," were added to the Constitution during Reconstruction and were expressly designed to enhance the power of the federal government while restricting the power of the states. 165

The Thirteenth Amendment prohibits slavery, and the Fifteenth Amendment guarantees all citizens the right to vote. The remaining Civil War Amendment, the Fourteenth, contains five sections; sections 1 and 5 are directly relevant to this Comment. Section 1 protects the "privileges or immunities" of citizens, prohibits the states from depriving any person of "life, liberty, or property, without due process of law," and directs that the states deny no person "the equal protection of the laws." 166 Thus, section 1 provides individuals with three protections against the states: guarantees as to privileges or immunities, due process, and equal protection. Section $\mathbf{5}$ of the Fourteenth Amendment provides that "[t]he Congress shall have power to enforce, by appropriate legislation, the provisions of this article." 167 The Thirteenth and

162 Fisher, supra note 158, at 715 (quoting 7 MESSAGES AND PAPERS OF THE PRESIDENT, supra note 159, at 3210).

163 See Ross, supra note 156, at 313-14 n.10 (citing 21 CoNG. REc. 2608 (1890)

(remarks of Senator Washburn)).

164 See id. at 314 n.10.

165 See Gregory v. Ashcroft, 111 S. Ct. 2395, 2405 (1991).

166 U.S. CoNST. amend. XIV, § 1.

${ }^{167}$ Id. amend. XIV, § 5. 
Fifteenth Amendments also conclude with enforcement provisions that are nearly identical to section $5 .^{168}$

The RJA, the FOCA, and the RFRA all depend upon one or more of the substantive guarantees of section 1 . For example, the Equal Protection Clause prohibits unequal treatment based on race, ${ }^{169}$ thus providing a Fourteenth Amendment right which the RJA would enforce. Similarly, the right to have an abortion is a liberty right protected by the Fourteenth Amendment's Due Process Clause (at least as long as Roe continues to be good law), ${ }^{170}$ thus providing a Fourteenth Amendment right which the FOCA would enforce. Additionally, the Equal Protection Clause applies to gender discrimination, albeit to a lesser extent than to situations involving race. ${ }^{171}$ The Equal Protection Clause thus provides an additional Fourteenth Amendment basis for the FOCA. Finally, because the Free Exercise Clause of the First Amendment applies to the states via the Due Process Clause of the Fourteenth Amendment, ${ }^{172}$ the RFRA could be said to enforce the Fourteenth Amendment's guarantee of due process.

Yet, in order to enact any of these bills, Congress must give force to constitutional rights beyond the perimeters of those rights as defined by the Court. As we shall see, Congress has broad power under Section 5 of the Fourteenth Amendment and such legislation is not unprecedented. In addition, Congress has broad power under the nearly identical enforcement provisions of the Thirteenth and Fifteenth Amendments. The Court has held the Fifteenth Amendment enforcement power to be coextensive with the section 5 power; ${ }^{173}$ and there is no reason to believe that cases interpreting the Thirteenth Amendment are not equally applicable to section 5.

168 See id. amend. XIII, § 2; id. amend. XV, § 2.

169 See, e.g., Brown v. Board of Educ., 347 U.S. 483 (1954) (holding that segregation in public schools denies children of African descent the equal protection of the laws guaranteed by the Fourteenth Amendment).

${ }_{170}$ See supra notes 80-83 and accompanying text.

171 See Craig v. Boren, 429 U.S. 190 (1976) (noting that the ability of females to purchase nonintoxicating beer at a younger age than males is a violation of the Equal Protection Clause of the Fourteenth Amendment); Mississippi Univ. for Women v. Hogan, 458 U.S. 718 (1972) (holding that denying an otherwise qualified male admission to an all-female school of nursing violates the Equal Protection Clause of the Fourteenth Amendment).

172 See supra note 30.

173 See infra note 196 and accompanying text. 


\section{B. The Beginnings: Ex Parte Virginia}

In one of the earliest cases interpreting Congress's power to enforce the Civil War Amendments, Ex Parte Virginia, ${ }^{174}$ the Court upheld a section of the Civil Rights Act of 1875 that made it a crime for state officials to exclude any citizen from serving as a juror on account of the citizen's race, color or previous condition of servitude. ${ }^{175}$ This legislation created a sword for persons discriminatorily excluded from juries, whereas the Constitution had provided only a shield for defendants against prosecution in a court with a discriminatorily chosen jury. ${ }^{176}$ The Court, echoing its broad interpretation of the Necessary and Proper Clause in McCulloch v. Maryland, ${ }^{177}$ stated that "[w]hatever legislation is appropriate, that is, adapted to carry out the objects the amendments have in view . . ., is brought within the domain of congressional power. ${ }^{\text {178 }}$ Writing for the majority, Justice Strong emphasized that the Thirteenth and Fourteenth Amendments explicitly give Congress the power to enforce their provisions ${ }^{179}$ and that the Constitution authorizes "congressional interference and compulsion in the cases embraced within the Fourteenth Amendment." ${ }^{180}$

The Court's Fourteenth Amendment holding in Ex Parte Virginia has remained firm. ${ }^{181}$ Additionally, the Court's Thirteenth Amendment holding, although at one time limited by the Civil

174100 U.S. 339 (1879).

175 See id. at 349 (upholding the Act of March 1, 1875, ch. 114, §§ 3-4, 18 Stat. 336 (current version at 18 U.S.C. $\$ 243$ (1988))).

${ }^{176}$ This "shield" aspect of the Fourteenth Amendment was upheld in Strauder v. West Virginia, 100 U.S. 303 (1879).

17717 U.S. (4 Wheat.) 316 (1819). The Necessary and Proper Clause gives Congress authority to enact laws aimed at carrying out the powers granted to it by the unamended body of the Constitution. The clause reads: "The Congress shall have Power ... [t] mo make all Laws which shall be necessary and proper for carrying into Execution the foregoing Powers, and all other Powers vested by this Constitution in the Government of the United States, or in any Department or Officer thereof." U.S. CONST. art. I, § 8. In a famous opinion written by Chief Justice John Marshall, the Court held in $\mathrm{McCulloch}$ that Congress had the constitutional authority to create a bank because creating a bank was a necessary and proper means for executing the specifically enumerated congressional duties of raising revenue, collecting taxes, borrowing money, and regulating commerce. See McCulloch, 17 U.S. (4 Wheat.) at 422-23.

${ }^{178}$ Ex Parte Virginia, 100 U.S. at $345-46$.

179 See id. at 347 .

180 See id. at 348 .

181 See infra notes 203-07 and accompanying text. 
Rights Cases, ${ }^{182}$ was reestablished in Jones $v$. Alfred $H$. Mayer Co. ${ }^{183}$ and has since gone undisturbed. In the Civil Rights Cases the Court held that the Thirteenth Amendment's prohibition of slavery restricts both private and governmental action. ${ }^{184}$ However, in striking down a law prohibiting race discrimination in public accommodations, the Court limited Congress's ability to define and remedy the badges of slavery. ${ }^{185}$ In Jones the Court removed that limitation, upholding a provision of the Civil Rights Act of 1866 that prohibits race discrimination in private transactions involving property, ${ }^{186}$ and declaring that Congress can define and remedy "the badges and the incidents of slavery." 187

Yet the Court has never held that the Thirteenth Amendment itself does "anything more than abolish slavery."188 For example, in Palmer $v$. Thompson ${ }^{189}$ the Court rejected a Thirteenth Amendment challenge to a city's decision to close its public swimming pools rather than comply with a desegregation order. In Palmer, the

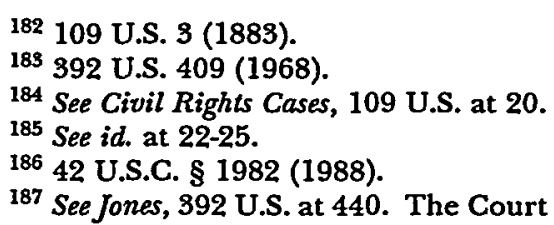
power Congress could prohibit and remedy most forms of private discrimination by enacting Title II of the Civil Rights Act of 1964. See id. at $441 \mathrm{n} .78$ (citing Title II of the Civil Rights Act of 1964, 42 U.S.C. $\$ 2000$ (1988); Katzenbach v. McClung, 379 U.S. 294 (1964) (upholding the enforcement of a congressional prohibition against racial discrimination in the context of a restaurant); Heart of Atlanta Motel, Inc. v. United States, 379 U.S. 241 (1964) (upholding a congressional prohibition of racial discrimination in places of public accommodation)). The Court thought this rendered its discussion somewhat "academic." Id. But when Congress drafted the Civil Rights Act of 1964, Jones had not yet been decided and Congress faced a dual obstacle presented by the Civil Rights Cases-an inability to define the badges of slavery under the Thirteenth Amendment and a state action requirement under the Fourteenth Amendment. After much discussion and controversy, Congress based Title II on the commerce power rather than on the enforcement powers of the Civil War Amendments. Jones overruled the Thirteenth Amendment holding of the Civil Rights Cases, but the state action doctrine is still good law. Remarkably, new historical research shows that in the $1960 \mathrm{~s}$, the Court was ready to overturn the state action doctrine and thus give Congress the ability to prohibit private sector discrimination under the Fourteenth Amendment. See Neil H. MacBride, Note, The Politics of Public Accommodations: The Search for a Constitutional Basis for Title II, 8 J.L. \& POL. 437, 439, 467 (describing the debate over whether to base Title II on $\$ 5$ or on the Commerce Clause and arguing that the Supreme Court was prepared to uphold Title II on the $\$ 5$ power).

${ }^{188}$ Memphis v. Greene, 451 U.S. 100, 125-26 (1980).

189403 U.S. 217 (1970). 
Court explicitly referred the problem to Congress to address under its enforcement power:

[A]lthough the Thirteenth Amendment is a skimpy collection of words to allow this Court to legislate new laws to control the operation of swimming pools throughout the length and breadth of this Nation, the Amendment does contain other words that we held in Jones v. Alfred H. Mayer Co. could empower Congress to outlaw badges of slavery. ${ }^{190}$

So, in Thirteenth Amendment jurisprudence, the Court readily accepts congressional power to prohibit conduct that does not itself violate the Constitution. ${ }^{191}$

\section{The Modern Trend: The Voting Rights Cases}

The modern conception of Congress's power under the Civil War Amendments emerged in the 1960s in a series of cases involving conflicts over federal voting-rights laws. Like Ex Parte Virginia, these cases interpret Congress's powers very broadly. The first of these cases was a Fifteenth Amendment case, South Carolina v. Katzenbach, ${ }^{192}$ in which the Court upheld a section of the Voting Rights Act of 1965 that temporarily suspended literacy tests in states or political subdivisions with less than fifty percent voter registration. ${ }^{193}$ Yet in Lassiter $v$. Northampton County Board of Elections, ${ }^{194}$ the Court had held that a state may, consistent with the Fifteenth Amendment, condition the right of suffrage on literacy tests. In South Carolina, the Court noted that Lassiter had left open the possibility that a literacy test, fair on its face, might be unfairly administered and held that such was the situation in the case before it. ${ }^{195}$ More broadly, the Court held that Congress's power under Section 2 of the Fifteenth Amendment was the same

$190 \mathrm{Id}$. at 227.

191 In Runyon v. McCrary, 427 U.S. 160 (1976), the Court reaffirmed this principle by upholding a statute that prohibits racial discrimination in the making and enforcing of contracts. Even the dissenters in Runyon did not question "the power of Congress" to prohibit private discrimination in the making of contracts; the dissenters simply thought that the statute at issue was not designed to reach private discrimination. See id. at 192 n.2 (White, J., dissenting). In Patterson v. McLean Credit Union, 491 U.S. 164 (1989), the Court declined an opportunity to overrule Runyon.

192383 U.S. 301 (1966).

193 See id. at 323 (upholding the Voting Rights Act, Pub. L. No. 89-110, § 4(a), 79 Stat. 437,438 (1965) (current version at 42 U.S.C. $\$ 1973 b(a)(1988)$ )).

194360 U.S. 45 (1959).

195 See South Carolina, 383 U.S. at 333. 
as Congress's power under the Necessary and Proper Clause ${ }^{196}$ and quoted Justice Marshall's famous test from McCulloch: "Let the end be legitimate, let it be within the scope of the constitution, and all means which are appropriate, which are plainly adapted to that end, which are not prohibited, but consistent with the letter and the spirit of the constitution, are constitutional."197

In City of Rome $v$. United States, ${ }^{198}$ the Court again illuminated Congress's broad powers under Section 2 of the Fifteenth Amendment. The Court held that Congress could prohibit electoral schemes with discriminatory effects, ${ }^{199}$ even though it held on the same day in City of Mobile $v$. Bolden, ${ }^{200}$ that such schemes do not of themselves violate the Fifteenth Amendment. Justice Marshall, writing for the Court, declared that "Congress may prohibit practices that in and of themselves do not violate $\S 1$ of the Amendment" ${ }^{201}$ and identified the "appropriate" test of McCulloch and Ex Parte Virginia as the relevant measure of congressional power. ${ }^{202}$

Shortly after South Carolina v. Katzenbach, the Court decided Katzenbach $v$. Morgan, ${ }^{203}$ generally recognized as the Court's most deferential treatment of congressional power under the Civil War Amendments. ${ }^{204}$ Although Morgan was a voting rights case, the Court did not rely on the Fifteenth Amendment but rather on the Equal Protection Clause of the Fourteenth Amendment. At issue in Morgan was section $4(\mathrm{e})$ of the Voting Rights Act, ${ }^{205}$ which invalidated New York State's literacy test as applied to persons who had

${ }^{196}$ See id. at 326; see also Gaston County v. United States, 395 U.S. 287 (1969) (relying on South Carolina to hold that a county could not reinstate its literacy tests against the congressional prohibition).

${ }^{197}$ South Carolina, 383 U.S. at 326 (quoting McCulloch v. Maryland, 17 U.S. (4 Wheat.) $316,421(1819)$ ).

${ }^{198} 446$ U.S. 156 (1980).

199 Id. at 179 .

200446 U.S. 55 (1980).

201 City of Rome, 446 U.S. at 177.

202 See id. City of Rome also verified that the enforcement powers of the Fourteenth and Fifteenth Amendments are coextensive. The majority relied on Fourteenth Amendment cases. See id. at 176-77, 179-80. Even though he dissented, then-Justice Rehnquist agreed that "the nature of the enforcement powers conferred by the Fourteenth and Fifteenth Amendments has always been treated as coextensive." See id. at 207 n.1 (Rehnquist, J., dissenting).

203384 U.S. 641 (1966).

204 See Lawrence G. Sager, Fair Measure: The Legal Status of Underenforced Constitutional Norms, 91 HARV. L. REV. 1212, 1229 (1978).

${ }^{205} 42$ U.S.C. § $1973 b(e)(1988)$. 
completed the sixth grade in Puerto Rican schools. The Court held that Congress could, under Section 5 of the Fourteenth Amendment, invalidate such tests as violative of the Equal Protection Clause. ${ }^{206}$ Additionally, the Court held that, as with the Fifteenth Amendment, the standard of McCulloch is to be applied in determining what constitutes appropriate legislation: " $\$ 5$ [of the Fourteenth Amendment] is a positive grant of legislative power authorizing Congress to exercise its discretion in determining whether and what legislation is needed to secure the guarantees of the Fourteenth Amendment." 207

The Court, in an opinion by Justice Brennan, offered two rationales for its broad holding. First, the Court suggested that Congress could have intended to enhance Puerto Ricans' political power in order to help them gain nondiscriminatory treatment throughout society. ${ }^{208}$ Under this rationale, it is the general discriminatory treatment (rather than the literacy test) that violates the Equal Protection Clause; the congressional grant to Puerto Ricans of greater voting rights helps them secure all other rights.

Alternatively, the Court asserted that Congress, contrary to the Court in Lassiter, could have found that the literacy test itself violated the Equal Protection Clause. ${ }^{209}$ This was a profound definition of congressional power. This rationale-the "second Morgan rationale"-holds that Congress can expressly disagree with the Court as to the reach of constitutional rights. The second Morgan rationale raises fundamental constitutional issues. For the Court to pay such deference to congressional determinations might be seen as endangering the fundamental constitutional principle of Marbury v. Madison ${ }^{210}$ that the judiciary has the last word in interpreting the Constitution: "[i]t is emphatically the province and duty of the judicial department to say what the law is."211 Additionally, as Justice Harlan noted in his dissent in Morgan, if Congress has the power to expand the scope of constitutional rights, then it would seem to follow that Congress also has the power to

\footnotetext{
206 See Morgan, 384 U.S. at 658.

207 Id. at 651.

${ }^{208}$ See id. at 652.

209 See id. at 653-56.

2105 U.S. (1 Cranch) 137 (1803).

211 Id. at 177. In Marbury, the Court invalidated the Judiciary Act of 1789 because it gave the Supreme Court original jurisdiction to issue writs of mandamus for federal officeholders. The Court thought that the Constitution did not give Congress the authority to grant jurisdiction of this sort to the Supreme Court. See id. at 176-80.
} 
restrict rights. ${ }^{212}$ However, the majority responded in a footnote that the power to "enforce" the Fourteenth Amendment does not include the power to "restrict, abrogate or dilute" its guarantees. $^{213}$

\section{The Ratchet Theory}

The majority's proposition in Morgan that Congress can expand but not contract Fourteenth Amendment rights has become known as the one-way "ratchet" theory. ${ }^{214}$ This section examines three scholarly defenses of the theory in order to better explain how Congress can expand constitutional rights where the Court has declined to do so.

The first defense is linguistic and maintains that the word "enforce" in the Fourteenth Amendment means "expand but not contract." 215 Professor Lawrence Sager has observed that this explanation is somewhat problematic because it ignores the possibility that in expanding the Fourteenth Amendment for one group Congress might be contracting it for another. ${ }^{216}$ For example, if the Court were to hold that affirmative action programs violate white persons' equal protection rights, a congressional attempt to "enforce" the Equal Protection Clause by expanding the rights of racial minorities through affirmative action would at the same time restrict the equal protection rights of the racial majority. ${ }^{217}$ Such a tug of war between Congress and the Court is precisely what the Morgan dissenters feared.

However, this problem can be solved by interpreting the ratchet theory to require the invalidation of any restriction on constitutional

212 See Morgan, 384 U.S. at 668 (Harlan, J., dissenting). However, the idea of allowing Congress to restrict rights may have been more appealing to Justice Harlan as a tool of argumentation than as an idea he was willing to embrace. When Justice Harlan was faced with an opportunity to approve congressional power to restrict the establishment right, he went out of his way to repair a statute so as to cure the potential congressional restriction. See Welsh v. United States, 398 U.S. 333, 344-67 (1970) (Harlan, J., concurring in the result); see also infra note 411.

213 See Morgan, 384 U.S. at 651 n.10.

214 See, e.g., Sager, supra note 204, at 1230.

215 See id. at 1231-32.

216 See $i d$. at 1231 .

${ }^{217}$ As Justice Kennedy put it, "[t]he process by which a law that is an equal protection violation when enacted by a State becomes transformed to an equal protection guarantee when enacted by Congress poses a difficult proposition for me." City of Richmond v. J.A. Croson, 488 U.S. 469, 513 (1988) (Kennedy, J., concurring in part and concurring in the judgment). 
rights. ${ }^{218}$ In other words, if the Court were to hold affirmative action programs unconstitutional then Congress cannot enact affirmative action programs. Were this not so, Congress could, for example, enforce the rights of women by restricting the free speech rights of anti-abortion demonstrators; enforce the rights of fetuses and embryos (assuming it could define the Fourteenth Amendment's meaning of "persons") by restricting the rights of women; or enforce the rights of racial minorities who are victims of hate crimes by restricting suspects' rights against unreasonable searches and seizures. The whole purpose of the ratchet theory is to prohibit the restriction of rights. That Congress is acting under the enforcement powers of the Civil War Amendments gives it no more ability to restrict rights than if it were acting under any other of its enumerated powers. The undoing of some Supreme Court decisions-those restricting one individual right while expanding another individual right-will simply have to await another Court. While this solution will render Congress powerless to remedy certain injustices, it is the only solution consistent with the structure and purpose of constitutional liberties; those liberties are designed to prevent a tyranny of the majority. ${ }^{219}$

A second defense of the ratchet theory is the federalism/ personal liberties distinction as articulated by Professor William Cohen. ${ }^{220}$ This theory holds that when Congress expands rights under the Fourteenth Amendment it is encroaching upon state authority. However, judicial action is not thought to be the appropriate response to this encroachment. This defense holds that while the judiciary must be called upon to safeguard individual liberties, the political process is the proper mechanism for preventing and correcting congressional usurpations of state power. The judiciary should trust that the political process will prevent legislative overreaching in matters of states' rights, according to this theory, because the legislature itself is made up of representatives

${ }^{218}$ See S. REP. NO. 321, 102d Cong., 2d Sess. 30 (1992) (arguing that the Human Life Bill introduced in the 97th Congress would have violated the ratchet effect by restricting the rights of women).

219 See supra text accompanying note 69.

220 See William Cohen, Congressional Power to Interpret Due Process and Equal Protection, 27 STAN. L. REV. 603, 613 (1975). Professor Herbert Wechsler was the first to expound this theory. See Herbert Wechsler, The Political Safeguards of Federalism: The Role of the States in the Composition and Selection of the National Government, 54 CoLum. L. REV. 543 (1954). Wechsler argued that "Congress acts . . . against the background of the total corpus juris of the states ... assumed to govern unless changed by [national] legislation." Id. at 545. 
from each of the states, who will look out for state interests. On the other hand, the theory concludes, when Congress restricts Fourteenth Amendment rights it is encroaching upon individual liberties, and the Court should not defer such issues to a majoritarian body, which is inherently less likely to protect individual rights. ${ }^{221}$

Recent cases addressing Congress's power to execute the Commerce Clause seem to support the federalism/personal liberties distinction. In Garcia v. San Antonio Metropolitan Transit Authori$t y,{ }^{222}$ a case that presented a contest between Congress's commerce power and the Tenth Amendment power of the states, the Court adopted the federalism/personal liberties distinction. ${ }^{223}$ Specifically, it held that Congress could prescribe a minimum wage for state government employees. This holding directly overruled National League of Cities v. Usery, ${ }^{224}$ in which the Court had held that a federal law setting the wages of state employees unconstitutionally interfered with 'the States' freedom to structure integral operations in areas of traditional governmental functions. ${ }^{\text {225 }}$ Justice Blackmun, writing for the majority in Garcia, claimed that the Court need not intervene on behalf of state interests because state interests are amply protected by the political safeguards inherent in the federal constitutional scheme.226 For example, the Court noted, the states are guaranteed equal representation in the Senate and the states exercise indirect control over the House of Representatives and the President by controlling electoral qualifications. ${ }^{227}$

Despite the High Court's acceptance of the federalism/ personal liberties distinction in Commerce Clause jurisprudence, the Court's attraction to this theory may prove to be rather ephemeral. Garcia was decided by a bare five to four majority, and in his dissent, thenJustice Rehnquist practically promised to overturn the decision at

221 See Sager, supra note 204, at 1236.

222469 U.S. 528 (1985).

223 See id. at 550 ("[T] he principal means chosen by the Framers to ensure the role of the States in the federal system lies in the structure of the Federal Government itself.").

224426 U.S. 833 (1976), overruled by Garcia v. San Antonio Metro. Transit Auth., 469 U.S. 528 (1985).

225 Id. at 852.

${ }^{226}$ See id.; see also South Carolina v. Baker, 485 U.S. 505 (1988) (holding that the denial of the federal income tax exemption for interest on bonds issued by state and local governments did not violate the Tenth Amendment because the state had not shown it was deprived of any right to participate in the national political process). ${ }^{227}$ See Garcia, 469 U.S. at 550-51. 
his earliest opportunity. ${ }^{228}$ Given the Court's current composition, its approval of the federalism/personal liberties distinction stands on precariously fragile ground. ${ }^{229}$ It is possible that the Court will reject the theory in favor of Justice Powell's interpretation of federalism. In his dissent in Garcia, Justice Powell asserted that a number of developments over the course of the twentieth century, including the direct election of senators, the weakening of the political parties at the local level, and the rise of national media, have made Congress less sensitive to state and local interests and more responsive to national constituencies. ${ }^{230}$ To his credit, Justice Powell alone argued for consistency in the Court's treatment of state interests and individual rights: "[o]ne can hardly imagine this Court saying that because Congress is composed of individuals, individual rights guaranteed by the Bill of Rights are amply protected by the political process. "231

In spite of Justice Powell's inability to imagine it, that is exactly what the Court is now saying. In Employment Division v. Smith, ${ }^{232}$ the Court explicitly held that the democratic process provides all the protection of religious liberty that is needed against generally applicable, religion-neutral laws. Similarly, in McCleskey $v$. $\operatorname{Kemp}$, $^{233}$ the Court was explicit in referring an alleged equal protection violation to "legislative bodies" under the assumption that these bodies are sufficiently able to safeguard individual rights. ${ }^{234}$ The Court's view that individual rights are amply protected by the political process is directly contrary to the argument of Professor Cohen and Justice Powell that individual rights must be protected by the judiciary because majoritarian

${ }^{228}$ See id. at 580 (Rehnquist, J., dissenting) ( ${ }^{\prime \prime}$ I do not think it incumbent on those of us in dissent to spell out further the fine points of a principle that will, I am confident, in time again command the support of a majority of this Court.").

${ }^{229}$ Some people expected the Court to overrule Garcia last term in New York v. United States, 112 S. Ct. 2408 (1992). See 1992 RFRA Hearings, supra note 4 (statement of Professor Ira Lupu at 13-14). This the Court declined to do, although it did resurrect the Tenth Amendment in Commerce Clause jurisprudence. The Court did so, however, without resorting to the "traditional government functions" analysis of National League of Cities and without disparaging the federalism/personal liberties distinction. See infra text accompanying notes 346-49; cf. Planned Parenthood v. Casey, 112 S. Ct. 2791, 2804 (1992) (reaffirming Roe v. Wade, 410 U.S. 113 (1973), an opinion which several members of the Court had previously sought to overturn).

${ }^{230}$ See Garcia, 469 U.S. at 565-66 n.9 (Powell, J., dissenting).

$231 \mathrm{Id}$. at $565 \mathrm{n} .8$ (Powell, J., dissenting).

232494 U.S. 872, 890 (1990).

233481 U.S. 279 (1987).

234 See id. at 319. 
bodies are insensitive to the concerns of individuals. Should the Court overrule Garcia and adopt Justice Powell's view that the Court must actively protect states' interests, it will have come full circle. It will have gone from holding that the legislative process protects state interests (Garcia) but not individual rights (e.g., Sherbert) to holding that the legislative process protects individual rights (e.g., Smith) but not state interests (Garcia overruled).

Even if the Court takes this route and completely discards the federalism/personal liberties distinction in Commerce Clause jurisprudence, it would not necessarily bode ill for congressional attempts to enforce individual rights. The Court specifically noted in National League of Cities $v$. Usery ${ }^{235}$ that its limitation on the commerce power does not control questions of Congress's power under Section 5 of the Fourteenth Amendment. ${ }^{236}$ As we shall see in greater detail, the Court has explicitly stated that "Congress is not limited by the same Tenth Amendment constraints that circumscribe the exercise of its Commerce Clause powers."237 This is as it should be-for unlike the Commerce Clause, the Fourteenth Amendment followed the adoption of the Tenth Amendment and was part of a great historical shift in power from the states to the national government. ${ }^{238}$ So the ratchet theory makes perfect sense in Fourteenth Amendment cases: when Congress expands rights it is serving the purpose of the Civil War Amendments to protect individual rights by curtailing the states' power; when Congress attempts to restrict rights it is unlawfully undermining that purpose.

The third defense of the ratchet theory is based on the superior factfinding capability of Congress as compared to the judiciary. ${ }^{239}$ Justice Brennan expounded this theory in Oregon v. Mitchell, ${ }^{240}$ in which the Court upheld Congress's nationwide extension of the ban on literacy tests as a prerequisite to voting ${ }^{241}$ despite the Court's

235426 U.S. 833 (1976), overruled by Garcia v. San Antonio Metro. Transit Auth., 469 U.S. 528 (1985).

${ }^{236}$ See id. at 852 n.17.

237 EEOC v. Wyoming, 460 U.S. 226, 243 n.18 (1983); see infra notes 291-321 and accompanying text.

${ }^{238}$ See Gregory v. Ashcroft, 111 S. Ct. 2395, 2405 (1991); see also infra notes 28992 and accompanying text.

239 See Sager, supra note 204, at 1232-35.

240400 U.S. 112 (1970).

241 See id. at 118 (upholding the Voting Rights Act Amendments of 1970, Pub. L. No. 91-285, § 201, 84 Stat. 314, 315 (1970) (current version at 42 U.S.C. § 1973b(b) (1988))). 
previous holding in Lassiter v. Northampton County Board of Elections $^{242}$ that conditioning the suffrage right on literacy tests does not violate the Constitution. The factfinding defense sees the controversy over congressional power in terms of a contest between state and federal legislative bodies. Because of the Supremacy Clause, the Court must defer to federal legislative choices over state legislative choices. Additionally, this defense contends, the Court should defer to congressional choices over the Court's own interpretations when Congress is able to "unearth new evidence in its investigation. ${ }^{243}$

Professor Sager criticizes the factfinding defense as insufficient to support the ratchet theory because the courts are unlikely to change their holdings in response to congressional factfinding. ${ }^{244}$ According to Professor Sager, the factfinding defense assumes "a legislative superiority in factfinding which is not self-evident." ${ }^{245}$ Yet this does not seem right. Compared to the Court, Congress is a more appropriate institution for investigating widespread social problems such as racial, gender, and religious inequality, and for devising solutions to those problems. The Court can only consider the facts contained in the record and the issues presented in the case before it. Individual cases do not present the Court with a full picture of widespread societal problems or with the full range of solutions to such problems. By contrast, Congress's consideration of factual and constitutional issues is confined only by the limits of its investigative zeal: Congress can hold hearings, collect information, and subpoena witnesses ad infinitum.

Granted, as Justice Harlan stressed in his dissent in Oregon $v$. Mitchell, the decisions Congress makes based on its factual investigations are moral in dimension: ${ }^{246}$ whether Puerto Ricans who have completed the sixth grade should have the right to vote regardless of their facility with English; whether literacy tests should be eliminated nationwide; whether women should have the right to an abortion; whether racial disparities in capital sentencing should be tolerated; whether government should burden religious conduct without a compelling state interest-these are clearly normative questions. But the fact that the ultimate decisions are normative

242360 U.S. 45, 53-54 (1959).

${ }^{243}$ Mitchell, 400 U.S. at 249 n.31 (Brennan, J.).

244 See Sager, supra note 204, at 1234.

$245 \mathrm{Id}$. at 1283.

${ }^{246}$ See Mitchell, 400 U.S. at 206 (Harlan, J.). 
does not mean that Congress is not institutionally appropriate for answering these questions. In Employment Division $v$. Smith, the Court explicitly referred this normative process to the legislative branch. ${ }^{247}$ In Mitchell, Justice Harlan also shared this confidence in the legislative process: "I fully agree that judgments of the sort involved here are beyond the institutional competence and constitutional authority of the judiciary. ${ }^{n 48}$ Justice Harlan simply thought that the Fourteenth Amendment did not protect voting rights. ${ }^{249}$ In fact, in his Morgan dissent, Justice Harlan depended heavily on Congress's ability to determine "legislative facts" distinguishing South Carolina. Justice Harlan had joined the Court's holding in South Carolina because there was a "voluminous legislative history, ${ }^{, 251}$ to demonstrate the pernicious effects of literacy tests on voting rights. But Justice Harlan cited as a reason for his dissent in Morgan that Congress had provided the Court with "no such factual data." 252 Thus, absent the state control of electoral qualifications he so desired, even Justice Harlan points us toward Congress as the appropriate branch to address widespread discriminatory practices.

The three defenses of the ratchet theory explain how it is that the Constitution allows Congress to expand but not contract Fourteenth Amendment rights. All three defenses retain some vitality. The linguistic defense reminds us that to "enforce" rights one cannot restrict rights. The federalism/personal liberties distinction embodies the notion that federalism concerns do not restrain Congress's power under the Civil War Amendments because those provisions were expressly designed to protect individual rights and to curtail states rights. Finally, the factfinding defense avers that Congress is a more appropriate institution than the.Court for investigating and remedying widespread violations of rights.

The ratchet effect might seem like an unfair means of approaching the Constitution because it gives Congress such one-sided power. But it is not unfair if the structure, purpose, and intent of the Bill of Rights and the Civil War Amendments is to protect

${ }^{247}$ See 494 U.S. 872, 889-90 \& n.5 (1990).

248 Mitchell, 400 U.S. at 206-07 (Harlan, J.).

249 See id. at 200 (Harlan, J.).

250 Katzenbach v. Morgan, 384 U.S. 641,669 (Harlan, J., dissenting).

251 Id. at 667 (Harlan, J., dissenting) (quoting South Carolina v. Katzenbach, 383 U.S. 301,309 (1966)).

${ }^{252}$ Id. at 669 (Harlan, J., dissenting). 
individual liberty. ${ }^{253}$ By ensuring that Congress can help protect individual rights but by preventing Congress from weakening those rights, the ratchet effect is completely consistent with the intent of the Framers and the purposes of the constitutional protections of individual liberty.

\section{E. The Principle of Marbury v. Madison: Cooper, Baker, and Powell}

As noted above, critics of the ratchet theory and the second Morgan rationale-that Congress can independently discern and remedy violations of constitutional rights-believe that Morgan endangers the fundamental principle established in Marbury $v$. Madison that the Court is the ultimate expositor of the Constitution. In addition to Marbury, three other cases are sometimes cited as establishing sweeping declarations of the Court's power over acts of Congress. However, analysis of these cases shows that they are plainly inapplicable to cases addressing the constitutionality of acts of Congress.

The first case is Cooper $v$. Aaron, ${ }^{254}$ in which the Court cited Marbury and stated "[t]his decision declared the basic principle that the federal judiciary is supreme in the exposition of the law of the Constitution, and that principle has ever since been respected by this Court and the Country as a permanent and indispensable feature of our constitutional system." ${ }^{255}$ However, Cooper should not be interpreted as establishing a limitation on Congress because Cooper did not involve a contest between Congress and the Court. Rather, Cooper involved a contest between a state that refused to comply with a school desegregation order and the federal courts' power to enforce the Fourteenth Amendment. ${ }^{256}$

The second case is Baker v. Carr, ${ }^{257}$ in which the Court stated:

Deciding whether a matter has in any measure been committed by the Constitution to another branch of government, or whether the action of that branch exceeds whatever authority has been committed, is itself a delicate exercise in constitutional interpreta-

253 See supra text accompanying note 69.

254358 U.S. 1 (1958).

255 Id. at 18 (citing Marbury v. Madison, 5 U.S. (1 Cranch) 137, 177 (1803)), quoted in Oregon v. Mitchell, 400 U.S. 112, 204 n.86 (1970) (Harlan, J.).

256 See id. at 4.

257369 U.S. 186 (1962). 
tion, and is a responsibility of this Court as ultimate interpreter of the Constitution. ${ }^{258}$

Like Cooper, Baker was not a case involving a contest between Congress and the Court. Rather, as an apportionment case, Baker involved a contest between state power over legislative apportionment and the federal courts' power under the Fourteenth Amendment. ${ }^{259}$ The above quoted statement in Baker was simply dictathe Court followed the statement with the conclusion that cases interpreting the division of power between branches of the federal government did not apply to the situation in Baker. ${ }^{260}$ So Baker does not establish any limits on congressional power.

In Powell v. McCormack, ${ }^{261}$ the Court cited Baker for the proposition that "it is the responsibility of this Court to act as the ultimate interpreter of the Constitution. ${ }^{262}$ Like Cooper and Baker, Powell also did not involve a contest between Congress and the Court. Powell involved a contest between the Court and a resolution of the House of Representatives. ${ }^{263}$ No duly enacted statute was at issue and for that reason Congress's section 5 power also was not at issue.

Thus, whatever the force of Cooper, Baker, and Powell, these cases do not apply to the issue of congressional power. If one searches the cases, sweeping declarations of legislative power can be found in equally irrelevant cases. For example, in Missouri, Kansas $\mathcal{E}$ Texas Railway v. May, no less a jurist than Oliver Wendell Holmes declared that "it must be remembered that legislatures are ultimate guardians of the liberties and welfare of the people in quite as great a degree as the courts." 264 Yet May, like Cooper, Baker, and Powell, presented a contest between state and federal power rather than a question of congressional power. In order to grasp the Court's treatment of congressional power, it is necessary to consider cases addressing that power.

$258 I d$. at 211.

259 See id. at 196.

260 Id. at 226.

261395 U.S. 486 (1969).

262 Id. at 549 (citing Baker v. Carr, 369 U.S. 186, 211 (1962)).

${ }^{263}$ See id. at $492-93$.

264194 U.S. 267, 270 (1904) (upholding against an equal protection challenge a state law directed solely against railroad companies). 


\section{F. The Burger and Rehnquist Courts Concur}

As in the voting rights cases, in comparatively recent cases the Court has continued to recognize the broad nature of Congress's power. For example, in Fullilove v. Klutznick ${ }^{265}$ the Court upheld a federal law setting aside ten percent of construction grants for racial minorities. Chief Justice Burger's opinion announcing the judgment of the Court stated that Congress acted within its section 5 power in that it could have determined that prevailing procurement practices perpetuated the effects of prior discrimination: ${ }^{266}$

Here we deal ... not with the limited remedial powers of a federal court, for example, but with the broad remedial powers of Congress. It is fundamental that in no organ of government, state or federal, does there repose a more comprehensive remedial power than in the Congress, expressly charged by the Constitution with competence and authority to enforce equal protection guarantees. ${ }^{267}$

Similarly, in Metro Broadcasting v. $F C C^{268}$ the Court upheld Congress's power to prevent future discrimination, without a finding of past discrimination, through the use of benign raceconscious measures. Even Justice O'Connor's dissent, which stated that section 5 was simply not relevant to a case involving federal agencies, recognized that some benign race-conscious measures are a valid exercise of Congress's section 5 power: ${ }^{269}$ "Congress has considerable latitude, presenting special concerns for judicial review, when it exercises its 'unique remedial powers under section 5 ..."270 Justice O'Connor distinguished City of Richmond $v$. $J . A$. Croson ${ }^{271}$ in which the Court had invalidated a municipal plan identical to the congressionally created scheme upheld in Fullilove. ${ }^{272}$ Justice O'Connor's majority opinion in Croson stated that ' $[t]$ he power to 'enforce' may at times also include the power to define situations which Congress determines threaten principles

265448 U.S. 448 (1980).

266 See id. at 478 (plurality opinion). The opinion also noted, however, that Congress employed "an amalgam" of its powers, including the spending power and the commerce power. Id. at 473 .

$267 \mathrm{Id}$. at 483 .

268110 S. Ct. 2997 (1990).

${ }^{269}$ See id. at 3030-81 (O'Connor, J., dissenting).

270 Id. at 3030 (O'Connor, J., dissenting) (quoting City of Richmond v. J.A. Croson, 488 U.S. $469,488(1990)$ ).

271488 U.S. 469 (1990).

272 See id. at 491 . 
of equality and to adopt prophylactic rules to deal with those situations." 278

\section{G. Oregon v. Mitchell: Does it Limit Morgan?}

Oregon $v$. Mitchell ${ }^{274}$ has been referred to as the case in which the Supreme Court upheld Congress's extension of the ban on literacy tests for voting to the whole nation. Mitchell has also been referred to as the source of Justice Brennan's factfinding defense of the ratchet theory. But another aspect of Mitchell is viewed by some as a limitation on Congress's power under Morgan. ${ }^{275}$ In fact, at congressional hearings on the FOCA, the Justice Department submitted a memorandum to Congress describing Mitchell as undercutting the second rationale of Morgan. ${ }^{276}$

In Mitchell, the Court unanimously upheld the ban on literacy tests but was badly split on other aspects of the challenged legislation: in five different opinions the Court upheld by a five to four margin a provision lowering the voting age to eighteen in federal elections and the Court struck, by the same margin, a provision lowering the voting age to eighteen in state elections. ${ }^{277}$ The holdings and opinions in Mitchell are crucial to understanding the scope of Congress's section 5 power because that case presented the question whether Congress can prohibit conduct that discriminates against classes of people, such as the aged, whom the Court affords only the lowest level of equal protection scrutiny. ${ }^{278}$

273 Id. at 490.

274400 U.S. 112 (1970).

275 See EEOC v. Wyoming, 460 U.S. 226, 262 (1983) (Burger, C.J., dissenting) ("I have always read Oregon $v$. Mitchell as finally imposing a limitation on the extent to which Congress may substitute its own judgment for that of the states . . ..").

276 See The Freedom of Choice Act of 1991: Hearings on H.R. 25 Before the House Subcomm. on Civil and Constitutional Rights, 102d Cong., 2d Sess. (1992) [hereinafter 1992 FOCA Hearings] (forthcoming 1993) (unpublished statements and memorandum on file with author) (memorandum of law appended to the statement of Timothy $\mathrm{E}$. Flanigan, Acting Assistant Attorney General, Department of Justice at 21) (citing Mitchell for the proposition that "[1]ater developments in the law have undercut Morgan as authority for a non-remedial reading of section $5^{\prime \prime}$ ); see also id. (unpublished statement of Professor Douglas W. Kmiec at $19 \mathrm{n.7}$ ) (“[Mitchell] is widely accepted as rejecting any expansive claim that section 5 empowers Congress to define constitutional guarantees.").

277 See Mitchell, 400 U.S. at 117-18 (Black, J.).

278 See Vance v. Bradley, 440 U.S. 93 (1979) (applying the rational basis test in an equal protection challenge to age discrimination); Massachusetts Bd. of Retirement v. Murgia, 427 U.S. 307 (1976) (per curiam) (same). That Mitchell preceded these cases does not have great significance, for the Court has never applied heightened 
In Mitchell, four Justices (in opinions by Justices Harlan and Stewart) thought both provisions relating to age were unconstitutional, four Justices (in opinions by Justices Douglas and Brennan) thought both provisions were constitutional, and Justice Black thought that the provision relating to federal office-holders was constitutional but the provision relating to state office-holders was unconstitutional. Thus, the Court upheld the voting age for federal elections and struck down the voting age for state elections. ${ }^{279}$

As to the holding regarding federal elections, four Justices believed that Congress could find that age discrimination violated the Equal Protection Clause. ${ }^{280}$ Justice Black sidestepped the Fourteenth Amendment question; he believed that a separate constitutional provision, article I, section $4,{ }^{281}$ gave Congress the authority to set the voting age. ${ }^{282}$ Thus, although the holding as to federal elections suggests that Congress can find age discrimination violative of the Equal Protection Clause, only four Justices so reasoned.

As to the voting age in state elections, the four dissenters on the federal elections issue became part of the new majority. Three Justices believed that Congress cannot remedy age discrimination under the Equal Protection Clause, ${ }^{283}$ and Justice Harlan believed that Congress could not address voting rights issues under the Fourteenth Amendment. ${ }^{284}$ Justice Black cast his vote with these four, but in a cagey opinion left open the possibility that Congress could find and remedy age discrimination or other equal protection violations which the Court had not previously recognized as within the ambit of the Equal Protection Clause.

scrutiny to age discrimination.

279 Following Mitchell, the Twenty-sixth Amendment, guaranteeing citizens eighteen years of age or older the right to vote in state and federal elections, was added to the Constitution. See U.S. CONST. amend. XXVI.

${ }^{280}$ See Mitchell, 400 U.S. at $141-44$ (Douglas, J.); id. at 280-81 (Brennan, J.) (joined by White and Marshall, JJ.).

281 "The Times, Places, Manner of holding Elections for Senators and Representatives shall be prescribed in each State by the Legislature thereof; but the Congress may at any time by law make or alter such Regulations, except as to the Places of chusing Senators." U.S. CONST. art. I, $\$ 4$.

282 See Mitchell, 400 U.S. at 119 (Black, J.).

283 See id. at 296 (Stewart, J.).

284 See id. at 200, 212-13 (Harlan, J.). Justice Harlan's opinion suggests that he also believed that Congress could not remedy age discrimination under the Equal Protection Clause. But Justice Harlan did not reach the age issue because he reasoned that the Fourteenth Amendment does not affect voting rights no matter which class of persons is at issue. See id. 
Justice Black thought that article I, section 2, in conjunction with the Tenth Amendment and the "whole Constitution," reserves to states the power to set qualifications for voters in state and local elections. ${ }^{285}$ Because Congress had attempted to "invade an area preserved to the States by the Constitution" ${ }^{286}$ without making any legislative findings that the legislation was needed to remedy discrimination based on race, Justice Black reasoned that the section 5 enforcement power had to give way to the constitutional reservations of state power. Justice Black thus seemed to be the fifth Justice in favor of tying the Equal Protection Clause to racial discrimination. However, he added an important caveat: "On the other hand, where Congress legislates in a domain not exclusively reserved by the Constitution to the States, its enforcement power need not be tied so closely to the goal of eliminating discrimination on account of race." 287 Essentially, Justice Black believed there were federalism barriers to Congress only when addressing forms of discrimination other than race discrimination.

So if Mitchell does represent a limitation, it is only a limitation on Congress's ability to remedy non-racial discrimination in situations where the Tenth Amendment or other constitutional provisions reserve power to the states. Yet, to extract even this limitation from Mitchell is a stretch requiring a least common denominator approach. Only three (at most four) Justices argued that Congress cannot prohibit age discrimination under its power to enforce the Fourteenth Amendment. ${ }^{288}$ That contention was flatly contradicted by the four Justices who said that Congress can set the age limits in both federal and state elections under its section 5 power. The question whether Congress can remedy age discrimination under its section 5 power was thus at best a tie. Any limitation on the section 5 power in Mitchell must therefore depend on the federalism argument presented by just one Justice. Moreover, since Mitchell the Court has specifically rejected federalism limitations on Congress's enforcement powers under the Civil War Amendments.

\footnotetext{
285 See id. at 124-26 (Black, J.).

${ }^{286} \mathrm{Id}$. at 130 (opinion of Black, J.).

${ }^{287} \mathrm{Id}$.

288 See supra notes $283-84$ and accompanying text.
} 


\section{H. Federalism: The Tenth and Eleventh Amendments-No Barrier to Congress's Power}

\section{Fitzpatrick v. Bitzer}

The alleged limitation of Mitchell appears similar to the limitation on Congress's Commerce Clause power in National League of Cities, the case overruled in Garcia. Both National League of Cities and Justice Black's opinion in Mitchell claim that certain state functions are inviolate as a matter of the Tenth Amendment and principles of federalism. But when Congress legislates under the enforcement power of the Civil War Amendments, the Court has rejected the claim that certain state functions are inviolate.

For example, in a Fifteenth Amendment case discussed previously, City of Rome v. United States, ${ }^{289}$ the Court upheld a section of the Voting Rights Act of 1965 even though it required a political subdivision of a state to submit all of its electoral changes-including changes in the Board of Education voting system-to the federal government for approval. The city claimed that the federal law violated principles of federalism. The Court responded with an unequivocal rejection of any sort of federalism limitation on Congress's power under the Civil War Amendments: "[P]rinciples of federalism that might otherwise be an obstacle to congressional authority are necessarily overridden by the power to enforce the Civil War Amendments 'by appropriate legislation.' Those Amendments were specifically designed as an expansion of federal power and an intrusion on state sovereignty." ${ }^{290}$

Nor is City of Rome confined to cases involving race discrimination. In the landmark case of Fitzpatrick $v$. Bitzer, ${ }^{291}$ the Court rejected this view. In Fitzpatrick, a gender discrimination case, the Court held that Section $\mathbf{5}$ of the Fourteenth Amendment works as a limitation on other provisions of the Constitution:

[W]e think that the Eleventh Amendment, and the principles of state sovereignty which it embodies are necessarily limited by the enforcement provisions of $\S 5$ of the Fourteenth Amendment. In that section Congress is expressly granted authority to enforce 'by appropriate legislation' the substantive provisions of the Fourteenth Amendment, which themselves embody significant limita-

289446 U.S. 156 (1980); see supra notes 198-202 and accompanying text.

290 City of Rome, 446 U.S. at 179.

291427 U.S. 445 (1976). 
tions on state authority. When Congress acts pursuant to $\S 5$, not only is it exercising legislative authority that is plenary within the terms of the constitutional grant, it is exercising that authority under one section of a constitutional amendment whose other sections by their own terms embody limitations of state authority. ${ }^{292}$

Specifically, in Fitzpatrick the Court held that Congress could bring the states, in their capacity as employers, within the coverage of Title VII of the Civil Rights Act of $1964^{293}$ and authorize the recovery of monetary damages against the states, even though the Eleventh Amendment would prohibit such awards absent a federal statute. ${ }^{294}$ The Eleventh Amendment, like the Tenth, is a reservation of power to the states; it prohibits a suit by a citizen against a state. The Court held in Fitzpatrick that Congress can create a cause of action to enforce the Equal Protection Clause of the Fourteenth Amendment even though such a cause of action would otherwise violate the Eleventh Amendment.

Politically, Fitzpatrick is a fascinating opinion: there were no dissenting opinions and then Justice Rehnquist, who later dissented in City of Rome, ${ }^{295}$ wrote the Court's opinion. Doctrinally, the case is historic. Fitzpatrick was a gender discrimination case and it thus extends the principle of City of Rome-that there are no federalism limitations on the enforcement powers of the Civil War Amendments-to cases involving forms of discrimination other than race. Although Congress originally passed Title VII pursuant to its Commerce Clause power, ${ }^{296}$ Congress relied on its section 5 power in enacting the 1972 amendments extending Title VII to cover the states. ${ }^{297}$ Thus, Fitzpatrick makes it clear that Congress's section 5 power enables it to prohibit forms of discrimina-

${ }^{292} I d$. at 456 (citation omitted).

29342 U.S.C. \$ 2000e (1988). Title VII prohibits employment discrimination.

${ }^{294}$ See Fitzpatrick, 427 U.S. at 456-57.

295 But see Fry v. United States, 421 U.S. 542, 559 (1975) (Rehnquist, J., dissenting) ("Congress may well be empowered under the legislative authority granted to it by the Fourteenth and Fifteenth Amendments to the Constitution to impose significant restrictions on what would otherwise be thought state prerogatives.") In another political twist to Fitzpatrick, then-Solicitor General Robert Bork submitted a long brief for the United States as amicus curiae urging the Court to recognize the historical shift in power from the states to the federal government produced by the Civil War Amendments. See Fitzpatrick, 427 U.S. at 446.

${ }^{296}$ See 2 STATUTORY HistoRy OF THE UNTTED STATES: CIVIL RIGHTS 1020 (Bernard Schwartz ed., 1970) [hereinafter U.S. STATUTORY HiSTORY].

297 See Fitzpatrick, 427 U.S. at 453 n.9. 
tion other than race discrimination. The alleged federalism limitation on congressional power to address non-racial discrimination, recited by Justice Black in Mitchell, is now defunct.

Moreover, at the time the Court decided Fitzpatrick, the minimum standard of scrutiny prevailed in equal protection challenges to gender discrimination. ${ }^{298}$ It was not until some six months after Fitzpatrick, in Craig v. Boren, ${ }^{299}$ that the Court held gender to be a protected class in equal protection cases. While it is arguable that in previous cases the Court had applied a heightened scrutiny standard sub silentio, ${ }^{300}$ only one of those cases preceded the 1972 amendments to Title VII and in that case the Court plainly stated that it was applying the minimal "rational relationship" test. ${ }^{301}$ Congress thus prohibited gender discrimination under its section 5 power before the Court embraced gender as a protected class.

This argument gains force in light of Justice Stevens's concurrence in Fitzpatrick, where he declared that Connecticut had not, in fact, violated the Fourteenth Amendment. The plaintiffs originally claimed that the state's disparate retirement ages and benefits constituted a direct violation of the Fourteenth Amendment. The

298 To understand this Comment's argument, it is necessary to understand the basics of equal protection law. The Court applies three different standards of scrutiny to equal protection claims, depending on the kind of discrimination alleged. State action alleged to discriminate on the basis of race, color or national origin receives "strict scrutiny." That is, such laws must be necessary to further a compelling governmental interest. State action alleged to discriminate on the basis of gender receives an intermediate scrutiny. Such laws must be substantially related to an important governmental interest. All other classifications, including those based on age, disability, sexual orientation, and economics, receive the minimum rational basis scrutiny. Those classifications need only be rationally related to a legitimate governmental objective. See JOHN E. NOWAK ET AL., CONSTITUTIONAL LAW 448-49, 722 (2d ed. 1983). As Justice O'Connor has pointed out, the standards of review are not merely a "lawyers' quibble over words." Metro Broadcasting v. FCC, $110 \mathrm{~S}$. Ct. 2997, 3033 (1990) (O'Connor, J., dissenting). Rather, the "standard of review establishes whether and when the Court and Constitution allow the Government to employ ... classifications." Id. This Comment argues, inter alia, that because the Court has upheld and recognized congressional authority to prohibit state actions that, at the time Congress acted, would not have been subject to strict scrutiny, Congress has the power to help the Court define the limits of the Equal Protection Clause.

299429 U.S. 190 (1976).

${ }^{300}$ See Stanton v. Stanton, 421 U.S. 7 (1975); Weinberger v. Weisenfeld, 420 U.S. 636 (1975); Frontiero v. Richardson, 411 U.S. 677 (1973); Reed v. Reed, 404 U.S. 71 (1971); see also Tribe, supra note 80, at 1561-63.

${ }^{301}$ Reed, 404 U.S. at 76. 
district court did not reach that issue. But Justice Stevens, concurring in the judgment in Fitzpatrick, did reach the issue:

I do not believe plaintiffs proved a violation of the Fourteenth Amendment, and because I am not sure that the 1972 Amendments were "needed to secure the guarantees of the Fourteenth Amendment," see Katzenbach v. Morgan, I question whether $\$ 5$ of that Amendment is an adequate reply to Connecticut's Eleventh Amendment defense. ${ }^{302}$

Thus, the only judge or justice to reach the issue concluded that the plaintiffs had not made out a violation of the Fourteenth Amendment itself. Unlike Justice Stevens, the rest of the Court, well aware of the possibility that the Fourteenth Amendment did not prohibit Connecticut's retirement statute, did not believe it was necessary to reach that issue. Whether or not the state law violated the Fourteenth Amendment, Congress had prohibited such laws under its section 5 enforcement power.

If Congress could prohibit gender discrimination in 1972 under its section 5 power, it follows that Congress could, in 1992, prohibit age discrimination, sexual orientation discrimination, or disability discrimination under its section 5 power even though the Court has never held that the Fourteenth Amendment affords these classes of people anything more than the lowest level of equal protection scrutiny. ${ }^{303}$

This is not a radical proposition. As we have seen, in Thirteenth Amendment cases, the Court readily accepts the view that Congress is the appropriate branch to define and remedy the badges of slavery-badges that the Court has never held violative of the Thirteenth Amendment. ${ }^{304}$ Additionally, in the field of disability discrimination, Congress frequently has used its section 5 power. The Rehabilitation Act of 1973 was based on Section 5 of the Fourteenth Amendment, as the Court has twice noted. ${ }^{305}$ The

${ }^{302}$ Fitzpatrick, 427 U.S. at 458 (Stevens, J., concurring in the judgment) (citation omitted) (quoting Katzenbach v. Morgan, 384 U.S. 641, 651 (1966)).

${ }^{303}$ See City of Cleburne v. Cleburne Living Center, 473 U.S. 432 (1985) (purportedly applying minimum rationality review to a challenge to zoning laws that discriminated against the mentally retarded); Vance v. Bradley, 440 U.S. 93 (1979) (applying the rational basis test in an equal protection challenge to age discrimination); Massachusetts Bd. of Retirement v. Murgia, 427 U.S. 307 (1976) (per curiam) (same); National Gay Task Force v. Board of Educ., 729 F.2d 1270 (1984) (holding that classifications based on sexual orientation are not suspect), aff'd by a divided Court, 470 U.S. 903 (1985).

${ }^{304}$ See supra notes $182-91$ and accompanying text.

${ }^{305}$ See Welch v. Texas Dep't of Highways \& Pub. Transp., 483 U.S. 469, 472 n.4 
Americans With Disabilities Act of 1990, ${ }^{306}$ which authorizes damages actions against the states, ${ }^{307}$ also relies on Congress's section 5 power. ${ }^{308}$ The Civil Rights Remedies Equalization Act of 1986, which waives the states' Eleventh Amendment immunity under Congress's section 5 power, applies its provisions not only to situations of disability discrimination but also to age and gender discrimination..$^{309}$ And the very statute at issue in Fitzpatrick, the 1972 amendments to Title VII, in addition to prohibiting race and gender discrimination, also prohibits discrimination based on religion. It is thus clear that if Mitchell established any federalism limitation (or any limitation at all) on Congress's ability to extend equal protection guarantees to forms of discrimination other than race discrimination, that limitation is now moribund-for Fitzpatrick holds that Congress can abrogate federalism barriers pursuant to its section 5 power even when it is remedying non-race discrimination.

In EEOC v. Wyoming, ${ }^{310}$ the Court again declared that federalism concerns do not block Congress's ability to exercise its section 5 power. In that case, the EEOC brought suit against the State of Wyoming under the Age Discrimination in Employment Act (ADEA), ${ }^{311}$ challenging the state's mandatory retirement of its game wardens at age fifty-five. The Court upheld the ADEA as a valid exercise of Congress's commerce power despite the Tenth Amendment. The Court declined to decide whether the ADEA would also be a valid exercise of Congress's section 5 power. ${ }^{312}$

(1987) (plurality opinion); Atascadero State Hosp. v. Scanlon, 473 U.S. 234, 244 n.4 (1985). In Atascadero, the Court held that Congress had not abrogated the states' Eleventh Amendment immunity to suit by enacting the Rehabilitation Act because Congress had not expressly stated its intention to abrogate that immunity. See id at 247. Congress then enacted the Civil Rights Remedies Equalization Act (CRREA), expressly stating its intent to abrogate the states' Eleventh Amendment immunity in the Rehabilitation Act. See 42 U.S.C. $\$ 2000$ d-7 (1988). The CRREA was itself enacted pursuant to Congress's $\$ 5$ power. See 132 CoNG. REC. S10,876 (daily ed. Aug. 1, 1985, pt. II) (statement of Sen. Cranston) (invoking $\$ 5$ of the Fourteenth Amendment and the Spending Clause as congressional authority for the Senate bill designed to overturn Atascadero); see also 132 CONG. REC. S15,105 (daily ed. Oct. 3, 1986) (statement of Sen. Cranston) (discussing letter from Department of Justice, Office of Legislative Affairs stating that the Senate bill to overturn Atascadero would be a constitutional exercise of congressional power).

30642 U.S.C. § 12102(2) (Supp. 1990).

${ }^{307}$ See id. $\$ 12202$ (Supp. 1990).

${ }^{308}$ See id. $\$ 12101(\mathrm{~b})(4)$. This section also cites the commerce power as authority for the Act.

${ }^{309}$ See supra note 305 .

310460 U.S. 226 (1983).

31129 U.S.C. $\$ \S 621-634$ (1988).

312 See EEOC, 460 U.S. at 243 . However, except for the district court reversed in 
But, the Court added, "[w]e do reaffirm that when properly exercising its power under $\S 5$, Congress is not limited by the same Tenth Amendment constraints that circumscribe the exercise of its Commerce Clause powers." ${ }^{313}$

Joined by Justices Powell, Rehnquist, and O'Connor, Chief Justice Burger dissented, claiming that Congress could only act under the enforcement powers of the Civil War Amendments "where a violation lurks." ${ }^{\text {"14 }}$ Chief Justice Burger claimed that Mitchell imposed a limitation on Congress's section 5 power that prevented Congress from so acting. ${ }^{315}$ The dissent stressed that because the Court had never decided whether age discrimination violates the Equal Protection Clause, the ADEA could only be sustained if "Congress can define rights wholly independently of our case law." $\$ 16$

The dissent's implication seems to be that Fitzpatrick was a legitimate exercise of congressional power because the Court recognizes gender discrimination as prohibited by the Equal Protection Clause. Yet, as we have seen, gender was not a protected class under the equal protection clause at the time the Court decided Fitzpatrick. Likewise, if the EEOC dissent were correct, the Americans With Disabilities Act would be unconstitutional as applied to the states, as would the Civil Rights Remedies Equalization Act because the Court has never held age or disability discrimination as receiving anything but the lowest level of constitutional scrutiny. ${ }^{317}$ As we shall see in greater detail, the very statute at issue in Fitzpatrick would be unconstitutional under the EEOC dissent's standard because that statute extended Title VII's prohibi-

EEOC, every federal court that has considered the issue has concluded that the ADEA is a valid section 5 enforcement statute. See id. at 234 \& n.6.

313 Id. at 243 n. 18.

314 Id. at 260 (Burger, C.J., dissenting)

${ }^{315}$ See id. at 262-63 (Burger, C.J., dissenting) (claiming that "[a]llowing Congress to protect constitutional rights that it has independently defined fundamentally alters our scheme of government").

${ }^{316} I d$. at 262 (Burger, C.J., dissenting).

${ }^{317}$ At oral argument in EEOC, the Solicitor General argued that by applying even the lowest level of constitutional scrutiny, i.e., the rational basis test, to cases of age discrimination, the Court had implicitly agreed with Congress that age is a protected class under the Equal Protection Clause. See EEOC, 460 U.S. at 261 n.7 (Burger, C.J., dissenting). This novel argument supports congressional authority to remedy discrimination somewhat independently of the case law. Yet it might also draw a sensible line against congressional overreaching. Congressional attempts to apply the Equal Protection Clause to entities to which the Court has not applied even the rational basis test, such as fetuses, would fail under this approach. 
tion on discriminatory effects even though a discriminatory purpose is necessary to violate the Fourteenth Amendment itself. Even the voting age provision for federal elections upheld in Mitchell would be unconstitutional (unless the Court thought that the separate reason for its constitutionality espoused only by Justice Black was a sufficient alternative basis for that provision). ${ }^{318}$

The Court also rejected a federalism limitation on Congress's section 5 power in Maher $v$. Gagne. ${ }^{319}$ In Maher, a working recipient of Aid to Families With Dependent Children (AFDC) sued a state official responsible for administering AFDC, alleging both statutory and constitutional violations. The parties had reached a settlement in which the recipient received substantially all of the relief she had sought in federal court. Even though no constitutional violation had been proved, the court awarded attorney's fees under the Civil Rights Attorney's Fees Awards Act of 1976. ${ }^{320}$ The Supreme Court agreed with the district court, holding that "even if the Eleventh Amendment would otherwise present a barrier to an award of fees against a State, Congress was clearly acting within its power under $\S 5$ of the Fourteenth Amendment in removing that barrier." ${ }^{321}$ It is clear there are no federalism barriers to Congress's section 5 power.

\section{Gregory v. Ashcroft: Federalism Sneaks in the Back Door}

In a recent case, Gregory $v$. Ashcroft, ${ }^{322}$ the Supreme Court again considered the ADEA. Although it was a Commerce Clause case, the Court went out of its way to address the Fourteenth Amendment. In Gregory, Missouri state court judges challenged the state's mandatory retirement provision. The state presented a Tenth Amendment defense. The Court found no violation of the ADEA because it believed that principles of federalism required it to adopt a "plain statement rule." ${ }^{\text {"23 }}$ That is, the Court believed it was obligated to find that Congress did not intend to abrogate the state's Tenth Amendment immunity unless Congress made its

318 See supra note 281 and accompanying text.

319448 U.S. 122 (1980).

32042 U.S.C. $\$ 1988$ (1988).

321 Maher, 448 U.S. at 132; see also Monnell v. New York City Dep't of Social Serv., 436 U.S. 658,690 n.54 (1978) (stating that there is no constitutional impediment under either the Tenth or Eleventh Amendments to holding municipalities liable under 42 U.S.C. \$ 1983 (1988)).

322111 S. Ct. 2395 (1991).

323 Id. at 2401. 
intention to do so "unmistakably clear in the language of the statute." I24 In light of the plain statement rule, the Court believed that without further guidance from Congress, it should interpret an exception in the ADEA for "appointee[s] 'on the policymaking level" to include judges. ${ }^{325}$ Therefore, the judges lost their challenge to the retirement provision.

The plain statement rule was a product of the Court's federalism concerns in considering the reach of a statute based on Congress's commerce power. $^{326}$ The Court noted, however, that since Congress might have enacted the ADEA based on section 5 of the Fourteenth Amendment, one could argue that the federalism concerns "that compel the result in this case might carry less weight." 327 "But," the Court declared in a remarkable statement, "this Court has never held that the [Fourteenth] Amendment may be applied in complete disregard for a State's constitutional

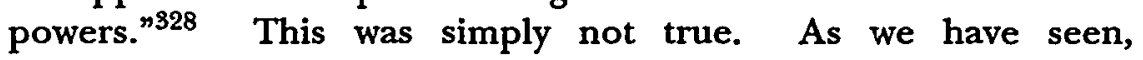
Fitzpatrick, City of Rome, and Maher established that Congress is unrestrained by federalism concerns (derived from either the Tenth or Eleventh Amendments) in legislating under the enforcement provision of the Civil War Amendments because those Amendments "were specifically designed as an expansion of federal power and an intrusion on state sovereignty. ${ }^{\text {n299 }}$ The only possibly relevant difference between Fitzpatrick and Gregory was that Fitzpatrick involved the federalism concerns of the Eleventh Amendment rather than the Tenth. However, since the Court in Gregory imported the plain statement rule into Tenth Amendment jurisprudence from Eleventh Amendment jurisprudence, ${ }^{330}$ one could hardly expect the Court to use this distinction.

The Court simply ignored Fitzpatrick's clear holding. The Court may be attempting to use Gregory to establish language stating that federalism concerns limit the Fourteenth Amendment. The Court might want to use that language later on to overturn statutes based on Congress's section 5 power.

In defense of its notion that 'the States' power to define the qualifications of their officeholders has force even as against the

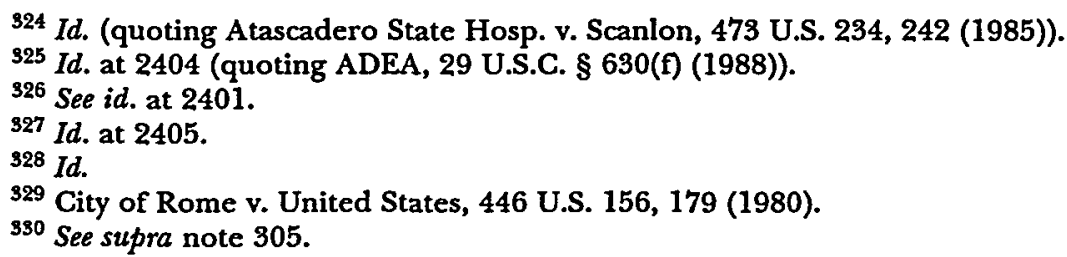


proscriptions of the Fourteenth Amendment," 331 the Gregory Court cited a line of cases holding that even though aliens are a discrete and insular minority who receive the highest level of protection under the Equal Protection Clause, that level of protection is lowered when states exclude aliens from important political functions in state government. ${ }^{332}$

The case that spawned this line was, ironically, Sugarman $v$. Dougal. $^{333}$ The irony lies in the fact that in Dougal the Court upheld an equal protection challenge to a state statute that discriminated against aliens. It was only in dictum, ${ }^{334}$ after the Court had reached its holding, that the Court stated that, as a matter of federalism, aliens' equal protection challenges to certain political functions would receive the lowest level of scrutiny under the Equal Protection Clause. ${ }^{335}$ In support of this notion, the Court cited Justice Black's opinion in Oregon v. Mitchell. ${ }^{336}$

Since its decision in Dougal, the Court has applied the dictum in several cases. These cases hold that state laws excluding aliens from positions as state troopers, ${ }^{337}$ public school teachers, ${ }^{338}$ and deputy probation officers ${ }^{339}$ are constitutional, while a state law excluding aliens from working as notaries public is unconstitutional. ${ }^{340}$ In Gregory, the Court concluded that " $[t]$ hese cases demonstrate that the Fourteenth Amendment does not override all principles of federalism. ${ }^{\text {341 }}$

The Court fails to notice, however, that in the Dougal line of cases no act of Congress was at issue. As Justice White said in dissent, "it is one thing to limit judicially-created scrutiny, and it is quite another to fashion a restraint on Congress' legislative authority, as does the majority; the latter is both counter-majoritarian and an intrusion on a co-equal branch of the federal government. ${ }^{\text {342 }}$ By

${ }^{331}$ Gregory, 111 S. Ct. at 2405.

332 See id.

${ }^{333} 413$ U.S. 634 (1973).

${ }^{354}$ See Foley v. Connelie, 435 U.S. 291, 303 (1978) (Marshall, J., dissenting) (noting that the political function doctrine in Dougal is dictum).

${ }^{335}$ See Dougal, 413 U.S. at 646-49.

${ }^{336}$ See id. at 647 (quoting Oregon v. Mitchell, 400 U.S. 112, 124-25 (1970) (Black,

J.) (footnote omitted)).

337 See Foley, 435 U.S. at 291.

338 See Ambach v. Norwick, 441 U.S. 68 (1979)

339 See Cabell v. Chavez-Salido, 454 U.S. 432 (1982).

${ }^{340}$ See Bernal v. Fainter, 467 U.S. 216 (1984).

${ }^{341}$ Gregory v. Ashcroft, 111 S. Ct. 2395, 2405 (1991).

342 Id. at 2410 (White, J., dissenting). 
importing the holdings from the aliens cases into an age discrimination case, the Gregory Court seems to be hinting that it will invalidate acts of Congress that tread on state functions regardless of the form of discrimination at issue.

To summarize Gregory, the Court dragged the Fourteenth Amendment into a Commerce Clause case, ignored clear Tenth and Eleventh Amendment precedent holding that no federalism analysis is even required under the Fourteenth Amendment, imposed an Eleventh Amendment-based rule of statutory construction on a Tenth Amendment case, and borrowed a limitation on the Fourteenth Amendment from a special class of cases addressing aliens' rights-a class of cases that says nothing about congressional power under that Amendment. The only good news for the Fourteenth Amendment in Gregory was that the limitation announced by the Court was merely a rule of statutory construction. ${ }^{343}$ Gregory will not apply in cases where Congress has clearly stated its intent to abrogate federalism barriers under the Civil War Amendments' enforcement powers.

It is vital that federalism barriers not be erected against Congress's section 5 power because federalism barriers are beginning to creep into the Court's interpretation of Congress's commerce power. Currently, Congress can regulate the states under its commerce power. This was established in Garcia v. San Antonio Metropolitan Transit Authority ${ }^{344}$ in which the Court upheld a federal minimum wage for state employees against a Tenth Amendment challenge and in Pennsylvania v. Union Gas Co. ${ }^{345}$ in which the Court upheld a provision of the Superfund law authorizing damages actions against the states despite the Eleventh Amendment. But in the Court's most recent treatment of the Commerce Clause, New York v. United States, ${ }^{346}$ the Court invalidated a provision of federal law that required the states to establish disposal sites for low-level radioactive waste produced in-state, enter into regional compacts with other states for disposal, or take title of the waste themselves and assume all liability for the waste. In an opinion by Justice O'Connor, the Court held that, while the

343 See Hilton v. South Carolina Pub. Rys. Comm'n, 112 S. Ct. 560, 566 (1991) (stating that the plain statement rule of Gregory should be treated as a rule of statutory construction "rather than as a rule of constitutional law").

${ }^{344} 469$ U.S. 528 (1985).

345491 U.S. 1 (1989).

${ }^{346} 112$ S. Ct. 2408 (1992). 
commerce power enables the federal government to preempt state regulation with its own regulations, principles of federalism embodied in the Tenth Amendment prohibit the federal government from directing the states to regulate activities when they choose not to do so. ${ }^{347}$ In reaching its holding, the Court extensively examined the history of the Constitution and concluded that the Constitution embodied a major shift in the role of the national government from one that regulated the states to one that regulates individuals. ${ }^{348}$ In dissent, Justice White claimed that the majority's analysis failed to acknowledge the major shift in the structure of the Constitution following the Civil War. That war, he declared, produced a change so profound that "the persons who helped to found the Republic would scarcely have recognized the many added roles the National Government assumed for itself. ${ }^{349}$

Gregory and New York seem to signal the Court's increasing concern for federalism issues. If federalism barriers become established in Commerce Clause cases, then the commerce power will be limited to private-sector regulation and congressional attempts to prohibit state-sponsored discrimination will fall primarily on the section 5 power. ${ }^{350}$ Yet, even if the Tenth and Eleventh Amendments limit the reach of the commerce power, surely the enforcement powers of the Civil War Amendments are on a different footing. For those amendments followed the Tenth Amendment and were "specifically designed as an expansion of federal power and an intrusion on state sovereignty." 351 The Civil War Amendments must be understood and applied in their historical context as part of a profound shift in power from the states to the national government. That is the meaning of the Court's opinions in City of Rome and Fitzpatrick.

347 See id. at 2424, 2428-29.

348 See id. at 2421-23.

349 Id. at 2444 n.3 (White, J., concurring in part and dissenting in part).

${ }^{350}$ Lest it appear that this Comment is simply a liberal tirade against an increasingly conservative Court, the reader is urged to note that this writer considers Garcia to have been wrongly reasoned and probably to have been wrongly decided as well. This writer believes that the Tenth Amendment does reserve to the states, as against the commerce power, certain functions necessary to sovereignty but that the Civil War Amendments give Congress absolute power to abrogate federalism barriers. 351 City of Rome v. United States, 446 U.S. 156, 179 (1980). 
III. Prognosis FOR THE RFRA, THE FOCA, AND THE RJA ${ }^{352}$

\section{A. The RJA}

In Morgan, the Court described the test for whether legislation is an "appropriate" exercise of the section 5 power as involving three steps. The courts must determine whether the statute at issue "may be regarded as an enactment to enforce" the Fourteenth Amendment, whether it is "plainly adapted to that end" and whether "it is not prohibited by but consistent with the "letter and spirit of the constitution."'353

Professor Laurence Tribe has identified three constitutional grounds on which Congress could enact the RJA. ${ }^{354}$ First, Congress could enact the RJA to remedy race discrimination against defendants charged with capital crimes. Second, Congress could enact the RJA to remedy race discrimination against victims of capital crimes. Third, Congress could enact the RJA to remedy "society's demeaning vision of blacks as second-class citizens. ${ }^{\text {"355 }}$ The bill as written takes all three approaches. ${ }^{856}$

The first ground would require Congress to prohibit discriminatory effects when the Court has declared, in McCleskey, that a discriminatory purpose is necessary to demonstrate a constitutional violation. ${ }^{357}$ Morgan, South Carolina, Mitchell, Metro Broadcasting, Fitzpatrick, and City of Rome support Congress's ability to do so. City of Rome provides particularly forceful support for the RJA. In that case the Court held that Congress could prohibit voting schemes with discriminatory effects even though it held the same day, in Mobile $v$. Bolden, that a discriminatory purpose is required to demonstrate that those schemes violate the constitution. Even then Justice Rehnquist's dissent in that case could accommodate the RJA. Justice Rehnquist believed that "congressional prohibition of some conduct which may not itself violate the Constitution" is a valid use

352 This section examines the constitutionality of the three bills under $\S 5$ of the Fourteenth Amendment. In some cases, there are other constitutional bases for the bills, such as the commerce power or the spending power. Those bases, while extremely important, are beyond the scope of this Comment.

${ }^{353}$ Katzenbach v. Morgan, 384 U.S. 641, 651 (1966) (quoting McCulloch v. Maryland, 17 U.S. (4 Wheat.) 316, 421 (1819)).

${ }^{354}$ See 136 CoNG. REC. S6891-92 (daily ed. May 24, 1990) [hereinafter Letter of Professor Tribe] (reprinting letter from Professor Tribe to Sen. Kennedy).

${ }^{355} \mathrm{Id}$. at $\mathbf{\mathrm { S } 6 8 9 2 .}$

${ }^{356}$ See S. 1249, 102d Cong., Ist Sess. \$§ 2(6), 3(a) (1991).

${ }^{357}$ See McCleskey v. Kemp, 481 U.S. 279, 298 (1987). 
of the enforcement power "if that prohibition is necessary to remedy prior constitutional violations by the governmental unit, or if necessary to effectively prevent purposeful discrimination by a governmental unit." clude that as a remedial matter it was necessary to place the burden of proving lack of discriminatory purpose on the localities." ${ }^{\text {"359 }}$ As Professor Tribe has noted, Justice Rehnquist only objected to Congress's ability to place an "irrebuttable presumption" of discriminatory purpose on the states when Congress had identified only discriminatory effects. ${ }^{360}$

The RJA creates no such irrebuttable presumption. Rather, the bill provides that a demonstration of discriminatory effects establishes a prima facie case of race discrimination. The State is then entitled to rebut the prima facie case by demonstrating that nonracial factors persuasively explain the disparities. ${ }^{361}$ Thus, unlike the statute at issue in City of Rome, which prompted Justice Rehnquist's dissent, the RJA creates no irrebuttable presumption of discriminatory purpose.

Moreover, City of Rome is not the only case demonstrating that Congress can prohibit discriminatory effects where the Constitution alone prohibits only discriminatory purposes. In Griggs v. Duke Power Co., ${ }^{362}$ the Court held that Title VII of the Givil Rights Act of 1964 prohibits employment practices with discriminatory effects, even though the Court has declared as a "basic equal protection principle that the invidious quality of a law claimed to be racially discriminatory must ultimately be traced to a racially discriminatory purpose. ${ }^{n 63}$ Of course, Congress passed Title VII pursuant to its commerce power. ${ }^{364}$ But as the Court recognized in Connecticut v. Teal, ${ }^{365}$ the same 1972 amendments that extended Title VII to the states under Congress's section 5 power "endorsed the disparate-impact analysis employed by the Court in Griggs. ${ }^{\text {"366 }}$ In Teal,

${ }^{358}$ City of Rome v. United States, 446 U.S. 156, 213 (Rehnquist, J., dissenting).

${ }^{359}$ Id. at 214 (Rehnquist, J., dissenting).

${ }^{360} I d$. at 215 (Rehnquist, J., dissenting), quoted in Letter of Professor Tribe, supra

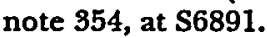

361 See S. 1249, 102d Cong., 1st Sess. § 3(a) (1991).

362401 U.S. 424, 432 (1971).

363 Washington v. Davis, 426 U.S. 229, 240 (1976); see also Village of Arlington Heights v. Metro. Hous. Dev. Corp., 429 U.S. 252, 264-68 (1977) (discussing the Fourteenth Amendment principle requiring a demonstration of discriminatory intent).

361 See U.S. STATUTORY HISTORY, supra note 296, at 1020.

${ }^{365} 457$ U.S. 440 (1982).

${ }^{366}$ Id. at 447 n.8. 
a case which presented a disparate-impacts claim against a state, the Court examined the legislative history of the 1972 amendments and found that Congress intended "to provide state and municipal employees with the protection that Title VII, as interpreted by Griggs, had provided to employees in the private sector. ${ }^{867}$ Thus, the Court recognized that, by extending disparate-impacts claims to cases against the states, Congress prohibited activity not prohibited by the Fourteenth Amendment itself. ${ }^{368}$ Although the Court in Teal did not directly address whether the application of Griggs to public employers was constitutional, the courts of appeals that have considered the issue have unanimously held that, under Morgan, the 1972 amendments are a valid exercise of the Congress's section 5 power. ${ }^{369}$ Moreover, the 1991 Civil Rights Act made disparateimpacts claims an explicit part of the statute. ${ }^{370}$ As applied to public employers, this new provision demonstrates once again that under its section 5 power, Congress can prohibit discriminatory effects or other activity not prohibited by the Fourteenth Amendment itself. ${ }^{371}$

In addition to the precedential support of Griggs and Teal, Professor Tribe's first approach to the RJA passes muster under the three-pronged Morgan test. The RJA is unquestionably an enactment to enforce the Equal Protection Clause. The findings of the bill refer repeatedly to equal protection rights ${ }^{372}$ and it is aimed at racial discrimination-the most suspect form of discrimination. As Justice Black stated in Mitchell, "the Civil War Amendments were unquestionably designed to condemn and forbid every distinction, however trifling, on account of race." ${ }^{\text {373 }}$

${ }^{367}$ Id. at 449.

${ }^{368}$ See also Dothard v. Rawlinson, 433 U.S. 321, 332 n.14 (1977) (“Congress expressly indicated the intent that the same Title VII principles be applied to governmental and private employers alike.").

${ }^{369}$ See Guardians Ass'n of New York City v. Civil Serv. Comm'n of New York, 630 F.2d 79, 88 (2d Cir. 1980), cert. denied, 452 U.S. 940 (1981); Scott v. City of Anniston, 597 F.2d 897, 899-900 (5th Cir. 1979), cert. denied, 446 U.S. 917 (1980); Blake v. City of Los Angeles, 595 F.2d 1367, 1372-74 (9th Cir. 1979), cert. denied, 446 U.S. 928 (1980); United States v. City of Chicago, 573 F.2d 416, 420-24 (7th Cir. 1978).

370 See 42 U.S.C.A. $\$ 2000 \mathrm{e}-2(k)$ (West Supp. 1992).

$371 \mathrm{It}$ is worth noting that $\mathrm{Smith}$ also represents an intent standard. By holding generally applicable religion neutral laws to a lower standard than laws that explicitly target religion, see supra note 33 and accompanying text, the Court is effectively requiring proof of a discriminatory intent.

372 See S. 1249, 102d Cong., 1st Sess. § 2 (1991).

${ }^{373}$ Oregon v. Mitchell, 400 U.S. 112, 127 (1970) (Black, J.) (emphasis added). 
The RJA is also plainly adapted to its enforcement goal. In Morgan the Court declared, "it is enough that we perceive a basis upon which Congress might predicate" an enforcement statute. ${ }^{374}$ The dissent described this test as a minimum "rationality" review. ${ }^{375}$ In introducing the Racial Justice Act, Senator Kennedy also introduced voluminous evidence demonstrating that a pattern of racial discrimination in capital sentencing appears "in jurisdiction after jurisdiction around the country. ${ }^{\text {376 }}$ Senator Kennedy's evidence demonstrated that such a pattern exists in Florida, Georgia, Maryland, Ohio, and Texas. Certainly, this evidence is more than enough for the Court to perceive a basis upon which Congress might have acted.

Finally, the RJA is not prohibited by and is consistent with the letter and spirit of the Constitution. As we have seen, federalism concerns do not constrain Congress's Fourteenth Amendment power. Yet, Gregory might mean that if the Court were strongly determined to find the RJA unconstitutional, it would do so under federalism principles. The Court did state in McCleskey that "[o]ne of society's most basic tasks is that of protecting the lives of its citizens and one of the most basic ways in which it achieves the task is through criminal laws against murder." ${ }^{\text {377 }}$ It is possible that the Court could classify this "basic task" as one belonging to the states the same way the Court in Gregory thought that "the States' power to define the qualifications of their officeholders" was a task belonging to the states. ${ }^{378}$ That would be a wholly irrational setback to the struggle for equality of the races in this country. The Fourteenth Amendment is immune from federalism limitations.

Professor Tribe's second approach to the RJA provides no problem in terms of counteracting the Supreme Court: in McCleskey the Court did not address whether the disparities in capital sentencing based on the race of victims violated the equal protection rights of the victims. Not having considered the issue, the Court could not and did not reject the idea that the disparity violated the victims' equal protection rights. ${ }^{379}$ Only if this section of the RJA

374 Katzenbach v. Morgan, 384 U.S. 641,656 (1966).

375 Id. at 666 (Harlan, J., dissenting).

376137 CONG. REC. S7380 (daily ed. June 6, 1991) (statement of Sen. Kennedy).

377 McCleskey v. Kemp, 481 U.S. 279, 297 (1987) (quoting Gregg v. Georgia, 428 U.S. 153, 226 (1976) (White, J., concurring)).

${ }^{378}$ Gregory v. Ashcroft, 111 S. Ct. 2395, 2405 (1991).

${ }^{379}$ Such a claim could not have been brought in McCleskey because no party had standing to raise the victim's rights. See Letter of Professor Tribe, supra note 354, at 
violates some other constitutional provision-and it does not-would there be a problem with the constitutionality of the RJA.

The RJA takes the third approach in declaring "the interest in ensuring equal justice under law may be harmed, not only by decisions motivated by explicit racial bias, but also by government rules, policies, and practices that operate to reinforce the subordinate status to which racial minorities were relegated in our society." 380 Professor Tribe notes that the Court validated this approach in Brown $v$. Board of Education. ${ }^{381}$ There the Court held that racial discrimination harms racial minorities because it "generates a feeling of inferiority as to their status in the community. ${ }^{\text {"82 }}$ Under this approach, the RJA is viewed as enabling racial minorities to gain nondiscriminatory treatment throughout society just as the first Morgan rationale held that granting Puerto Ricans an unencumbered suffrage right helped them gain nondiscriminatory treatment throughout society. Under this approach, it is not the racial disparities in capital sentencing that violate the Equal Protection Clause, but the inferior social status to which minorities are relegated when they cannot be free from discriminatory prosecutions and sentences that violates the Equal Protection Clause.

The third approach passes muster under the Morgan test. First, it is clearly aimed at enforcing the equal protection rights of minorities. Second, the Court could perceive a basis for the RJA in seeking to prevent the relegation of minorities to a "subordinate status" in society as that is one of the bill's stated goals. Finally, the third approach to the RJA would not violate any federalism principles embodied in the Tenth Amendment because, as we have seen, federalism principles do not, by definition, limit Congress's section 5 power.

Some have read $M c$ Cleskey as an outright invitation for Congress to enact legislation like the RFRA. ${ }^{383}$ This notion comes from the end of the McCleskey opinion, where the Court stressed that the

S6892. Because victims are not parties to criminal prosecutions and because victims of capital crimes tend to be dead, the protection of potential victims' rights is an especially difficult task for the Courts and an especially appropriate task for Congress.

${ }^{380}$ S. 1249, 102d Cong., 1st Sess. § 2(6) (1991). S6892.

381347 U.S. 483 (1954), cited in Letter of Professor Tribe, supra note 354, at

${ }^{382} I d$. at 494.

${ }^{383}$ See, e.g., 136 CoNG. REC. H9008 (daily ed. Oct. 5, 1990) (statement of Rep. Schroeder) (declaring that the RJA takes up a challenge from the Supreme Court to prohibit racial disparities in capital sentencing under Congress's $\$ 5$ power). 
concerns presented in the case are best addressed by legislative bodies. However, it is worth noting that the Court twice used the plural, "legislatures," in making that point. ${ }^{384}$ The Court was referring to state legislative determinations as to "the appropriate punishment for particular crimes, ${ }^{n}$ not legislative determinations as to equal protection violations. ${ }^{385}$ Nonetheless, Congress need not await an invitation to exercise its constitutional powers.

\section{B. The FOCA}

The immediate and obvious problem for the FOCA is that the Court could overrule Roe. Should this happen, one might wonder how Congress could protect the abortion right. But there are several reasons why this is not a dispositive issue. First, overruling Roe would not entirely remove the abortion right from the Fourteenth Amendment. Even those Justices who advocate overruling Roe recognize the abortion right as a "liberty interest protected by the Due Process Clause, ${ }^{386}$ albeit one with a low level of constitutional protection. Under this response, the right still exists and thus Congress can remedy its violation. The Solicitor General made this argument in an age discrimination case already discussed, EEOC $v$. Wyoming. ${ }^{387} \mathrm{He}$ argued that because the Court had subjected age discrimination cases to equal protection scrutiny (albeit the lowest level of scrutiny), the Court had implicitly recognized that age discrimination comes within the ambit of the Equal Protection Clause. ${ }^{388}$ The Court did not reject this argument because it never reached the Fourteenth Amendment issue, having upheld the statute at issue under Congress's commerce power. So the argument might well be valid.

Second, we simply are not likely to enter a post-Roe world and the RJA does not expand the abortion right beyond the perimeters established in Roe. Casey reaffirmed Roe's basic holding and the right Congress seeks to protect is thus clearly established (and likely to remain so now that a supporter of abortion-rights occupies the White House). Professor Douglas Kmiec criticized the original version of the FOCA, testifying to Congress that the bill expanded

${ }^{384}$ McCleskey v. Kemp, 481 U.S. 279, 319 (1987) (emphasis added).

385 Id.

386 Webster v. Reproductive Health Servs., 492 U.S. 490, 520 (1989) (plurality opinion).

${ }^{387} 460$ U.S. 226 (1983).

${ }^{388}$ See id. at 261 n.7 (Burger, C.J., dissenting). 
the abortion right beyond Roe and established "abortion on demand. ${ }^{389}$ In response to the criticism, Senator Cranston introduced the most recent version of the FOCA, which "make[s] it absolutely clear" that the FOCA does not establish any rights beyond Roe. ${ }^{390}$ As long as Casey is good law, the FOCA will build upon an established right.

Third, in a post-Roe world, Congress could define the substance of the abortion right under its section 5 power. Fitzpatrick, Morgan, South Carolina, City of Rome, Metro Broadcasting v. FCC, and the holdings of Mitchell as to the federal voting age and nationwide ban on literacy tests, support Congress's ability to do this. The opponents of the FOCA have tried to put these cases in a box by seizing on Justice Rehnquist's "remedial" characterization in his City of Rome dissent and on Justice Harlan's "remedial" characterization in his Morgan dissent. ${ }^{391}$ They claim that the first Morgan rationale only allows Congress to remedy past violations of the Constitution as defined by the Court and that the second rationale of Morgan, giving Congress broad power to disagree with the Court as to the scope of a right, was simply an alternative holding to which the Court would no longer adhere. ${ }^{392}$

This description of the first Morgan rationale is simply wrong. The first Morgan rationale holds that Congress can differ with the Court over the scope of a right when that right is necessary to eliminate other

${ }^{889} 1992$ FOCA Hearings, supra note 276 (statement of Professor Douglas Kmiec at 1). Professor Kmiec's declaration that Congress possessed the power to extend due process protection to embryos and fetuses, see $i d$. (statement of Professor Douglas Kmiec at 17-18 n.6 \& 32-34), but not to pregnant women should have given the committee some reason to doubt his analysis. If Congress lacks the power to expand the rights of women, whom everyone agrees are "persons" under the Fourteenth Amendment, then Congress must lack the power to expand the rights of fetuses and embryos, entities for which there is no consensus as to personhood. The Department of Justice made the same inconsistent (indeed ridiculous) argument as Professor Kmiec, see id. (statement of Timothy E. Flanigan, Acting Assistant Attorney General at $18 \mathrm{n} .23$ ), although the Department's intellectual inconsistency may be excused as the result of impossible political constraints.

390138 CONG. REC. S9027 (daily ed. June 25, 1992) (statement of Sen. Cranston).

391 See Katzenbach v. Morgan, $\$ 84$ U.S. 641, 667 (1966) (Harlan, J., dissenting).

392 See 1992 FOCA Hearings, supra note 276 (statement of Timothy E. Flanigan, Acting Assistant Attorney General at 20) (arguing that the FOCA has "no valid remedial purpose" because it does not prohibit practices the Court has declared unconstitutional); id. (statement of Professor Douglas W. Kmiec at 19) (stating that Morgan, "upon which pro-abortion supporters of FOCA so heavily rely for authority, merely approves of congressional action that is remedial and necessarily bounded by the interpretative meaning that the Supreme Court has drawn from the Constitution"). 
discriminatory practices. It is those other practices rather than the practice Congress is prohibiting that violate the Constitution. ${ }^{393}$ The "remedial" distinction is appealing because it seems to draw a bright line between valid and invalid acts of Congress: those addressing constitutional violations as defined by the Court are valid, whereas those addressing activity the Court has not declared unconstitutional are invalid. But this clearly is not the case. The first Morgan rationale still required Congress to disagree with a prior Court interpretation, as Justice Harlan's dissent made clear. ${ }^{394}$ Indeed, Justice Harlan would have had no reason to dissent if the first Morgan rationale did not require the Court to empower Congress to disagree with the scope of a right. Moreover, Justice Rehnquist's dissent in City of Rome recognizes "congressional prohibition of some conduct which may not itself violate the Constitution." 395 The "remedial" characterization of the first Morgan rationale is thus inaccurate both as a characterization of Morgan and as a characterization of Justice Rehnquist's dissent in City of Rome. Additionally, as recently as 1990 the Court rejected a remedial limitation on Congress's section 5 power in Metro Broadcasting $v . F C C .{ }^{396}$ In that case, the Court approved congressional authority to prohibit discrimination under its section 5 power without requiring Congress to unearth past constitutional violations: "[t]oday the Court squarely rejects the proposition that a governmental decision that rests on a racial classification is never permissi-

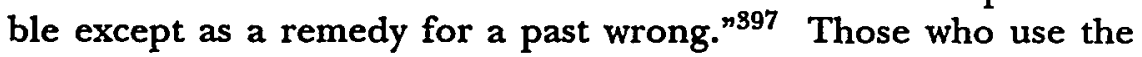
"remedial" characterization as a talisman against Congress's section 5 power are mistaken. It is clear that under Congress's section $\mathbf{5}$ power, Congress can prohibit restrictions on the abortion right whether or not the Court agrees that the Fourteenth Amendment encompasses an abortion right.

Fourth, the FOCA is based not simply on Congress's ability to protect the due process right to abortion. It is also based on Congress's ability to enforce the Equal Protection Clause. The FOCA sets forth a series of findings which include the finding that restrictions on the abortion right "discriminate between women who are able to afford interstate and international travel and women who

393 See Morgan, 384 U.S. at 652-53.

${ }^{394}$ See id. at 667-68 (Harlan, J., dissenting).

395 City of Rome, 446 U.S. 156, 213 (1980) (Rehnquist, J., dissenting).

396110 S. Ct. 2997 (1990).

${ }^{397}$ Id. at 3028 (Stevens, J., concurring). 
are not, a disproportionate number of whom belong to racial or ethnic minorities." 398 Protecting the equal protection rights of women and racial minorities does not require Congress to extend the Fourteenth Amendment to formerly unprotected classes of people. Gender and race discrimination are well within the ambit of the Equal Protection Clause as defined by the Court. ${ }^{399}$ Thus, like the RJA, the FOCA could be upheld as a measure that protects rights the Court clearly recognizes.

In the congressional hearings on the FOCA, Professor Kmiec and the Justice Department attacked the equal protection argument and cited Geduldig $v$. Aiello. ${ }^{400}$ That case held that a state classification denying benefits based on pregnancy did not violate the Equal Protection Clause. Geduldig established that the states may treat pregnant persons differently from nonpregnant persons without violating the Equal Protection Clause because, while the former group is exclusively female, the latter group is not exclusively male. ${ }^{401}$

However, Geduldig does not prohibit Congress from prohibiting pregnancy discrimination. If it were otherwise, then the Pregnancy Discrimination Act, ${ }^{402}$ as applied to the states, would be unconstitutional. This Act is an amendment to Title VII making pregnancy discrimination a form of gender discrimination.

Moreover, Geduldig does not prohibit Congress from granting women rights that will help them secure nondiscriminatory treatment throughout society. By passing the FOCA, Congress would be declaring that without control over their bodies and their reproductive futures, women cannot enjoy the equal protection of the laws with respect to jobs, housing, political participation, etc. This is a straightforward application of the first Morgan rationale: when women die or are permanently incapacitated or when they must travel great distances or bear significant costs to exercise control over their bodies, they cannot enjoy the blessings of liberty

${ }^{398}$ S. 25, Version 2, 102d Cong., 2d Sess. \$ 2(a)(2)(C) (1992).

${ }^{399}$ See, e.g., Craig v. Boren, 429 U.S. 190 (1976) (holding that gender is within the ambit of the Equal Protection Clause); Mississippi Univ. for Women v. Hogan, 458 U.S. 718 (1982) (gender); Brown v. Board of Educ., 347 U.S. 483 (1954) (race).

${ }^{100} 417$ U.S. 484 (1974), cited in 1992 FOCA Hearings, supra note 276 (statement of Timothy E. Flanigan, Acting Assistant Attorney General) (memorandum attached to unpublished statement at 20); id. (statement of Professor Douglas W. Kmiec) (unpublished statement at 20).

${ }^{401}$ See Geduldig, 417 U.S. at $496-97$ n.20.

40242 U.S.C. $\$ 2000 \mathrm{e}(\mathrm{k})$ (1988). 
or function as equal members of the polity. Moreover, Geduldig does not apply at all to situations of race discrimination. In considering the FOCA, the Senate Labor and Human Resources Committee explicitly relied on racial disparities: "[ $t]$ he mortality rate from illegal abortions was twelve times as great for women of color than for white women from 1972 to $1974 .{ }^{\text {"403 }}$

Without running through the Morgan analysis for every possible Fourteenth Amendment right protected by the FOCA, it is clear that the FOCA would pass muster under one or more of its constitutional bases. First, as we have seen, it is clearly aimed at enforcing Fourteenth Amendment rights. Second, it is plainly adapted to its enforcement goals. From the testimony and information provided to Congress in support of the FOCA, the Court could easily perceive a basis upon which Congress could conclude that denial of the abortion right violates due process and equal protection rights.

Finally, there is no way for federalism limitations to impede Congress's ability to enact the FOCA. Though the states may have some history of regulating abortion, ${ }^{404}$ it is decidedly not an interest that could be categorized as fundamental to state sovereignty. Though the Court may return to a federalism test in Commerce Clause jurisprudence that declares certain issues, such as the retirement age at issue in Gregory, as concerns central to the states' existence as states, the regulation of abortions is certainly not a governmental function central to the states' political existence. Abortion regulations do not sustain the states as political units. Thus, even if the Court were to take the extraordinary step of importing a federalism limitation into Fourteenth Amendment jurisprudence, that limitation would not protect state abortion laws from Congress's section 5 power.

\section{The RFRA}

One issue we have not yet addressed is whether Congress has the same power with regard to rights contained in the Bill of Rights which, unlike rights literally contained in the Fourteenth Amendment itself, are encompassed within the Fourteenth Amendment by

${ }^{103}$ S. REP. No. 321, 102d Cong., 2d Sess. 29 (1992).

104 This point has been seized upon by FOCA opponents. See Thomas L. Jipping, The Constitutionality of the Freedom of Choice Act, in 136 CoNG. REC. E1485 (daily ed. May 10, 1990) (statement of Rep. Dannemeyer) (arguing that "[s]tate legislatures exclusively determined abortion policy for more than 150 YEARS"). 
judicial construction. ${ }^{405}$ If the Morgan holding does not reach incorporated rights such as the free exercise right, then Morgan's historic holding would not support the RFRA.

The Court resolved this issue in Hutto v. Finney. ${ }^{406}$ In Hutto, the Court upheld an award of attorney's fees in an Eighth Amendment civil rights suit. The Court held that Congress could authorize an award of attorney's fees even though the Eighth Amendment, standing alone, would not provide for such an award. 407 This holding recognized that under Section 5 of the Fourteenth Amendment, Congress can enforce incorporated rights. In fact, the Eleventh Amendment would have prohibited monetary awards but for the federal statute. ${ }^{408}$ Nonetheless, the Court held that "Congress has plenary power to set aside the States's immunity from retroactive relief in order to enforce the Fourteenth Amendment. ${ }^{\text {409 }}$

In Hutto, then Justice Rehnquist dissented, declaring that Congress's power under Fitzpatrick is not the same with regard to incorporated rights as it is with regard to the prohibitions contained "in haec verba in the language of the Fourteenth Amendment

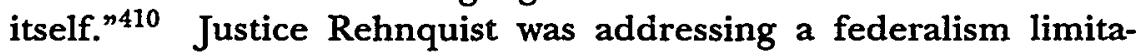
tion. So even if his view would now carry a majority, it would only be relevant if the RFRA were to implicate the Tenth or Eleventh Amendments. But it seems hard to imagine that Chief Justice Rehnquist's view would carry a majority, regardless of the Court's composition. Congress's ability to remedy violations of incorporated rights is well established: it is recognized implicitly in every $\S 1983$ action for the violation of incorporated rights. ${ }^{411}$ In fact,

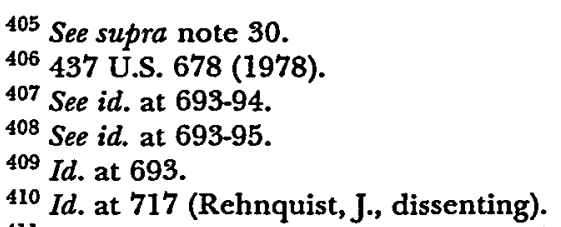

${ }^{411}$ In addition to Congress's $\$ 5$ power, three Justices have argued that Congress's power under the Necessary and Proper Clause enables it to expand the free exercise right-even if Congress thereby diminishes the establishment right as interpreted by the Court. In Welsh v. United States, 398 U.S. 333 (1970), Justice White, joined by Chief Justice Burger and Justice Stewart, argued that even if the Free Exercise Clause "does not by its own force require exempting devout objectors from military service," Congress can create such an exemption under its power to execute its military powers. Id. at 371 (White, J., dissenting). Justice White, citing Morgan, stated that Congress could, in exercising its power to execute its military powers, "take account of the First Amendment and ... avoid possible violations of the Free Exercise Clause." Id. (White, J., dissenting). Yet the rule created by Congress would have 
it seems to be recognized in Justice Rehnquist's opinion for the Court in Fitzpatrick, where the Court upheld a statute that prohibits religious discrimination. Title VII, both as originally enacted and as extended to the states under Congress's section 5 power, prohibits employment discrimination based on "race, color, religion, sex, or national origin. ${ }^{412}$

The foregoing makes it clear that the RFRA would pass the Morgan test. So long as Chief Justice Rehnquist's view in Hutto does not prevail, the RFRA would clearly be enacted to enforce a Fourteenth Amendment due process right-the incorporated right to the free exercise of religion. The Court could also "perceive a basis upon which the Congress might resolve the conflict as it did." 413 In the hearings on the RFRA, Congress faced an outpouring of support for the bill and of hostility to Smith. Liberal and conservative organizations alike supported the bill and pleaded with Congress to restore religious freedom. ${ }^{414}$ Congress could have concluded that the most appropriate means for dealing with the problem was to restore the Sherbert test.

Finally, the RFRA would not violate other constitutional provisions. The RFRA could involve federalism problems only if federalism limitations are improperly applied to Fourteenth Amendment cases. But on the hypothesis that the rule of statutory construction in Gregory somehow becomes translated into a constitutional rule, the RFRA could certainly conflict with federalism concerns. For example, a state could fire its Sabbatarian employees who are unwilling to work on Saturdays and who perform important governmental functions, implicating the Tenth Amendment. Or those same employees could sue the state, not for reinstatement, but for damages under the RFRA, implicating the Eleventh Amendment. But, to risk repetition, federalism principles do not restrain Congress's $\$ 5$ power.

violated the Court's interpretation of the Establishment Clause by favoring the religious over the nonreligious. See id. at 356-58 (Harlan, J., concurring in the result) (citing Walz v. Tax Comm'n, 397 U.S. 664 (1970)). The majority sidestepped the constitutional problems by interpreting the statute so as to exempt both religious and nonreligious objectors. See id. at 343-44. The dissent in Welsh thus advocates congressional power to restrict the Court's interpretation of constitutional rights: three Justices would have approved congressional power to expand the free exercise right and to contemporaneously restrict the establishment right. This seems to be the only opinion to advocate a two-way ratchet.

41242 U.S.C. $\$ 2000 \mathrm{e}-2$ (a) (1988) (emphasis added).

113 Katzenbach v. Morgan, 384 U.S. 641, 653 (1966).

414 See generally 1990 RFRA Hearings, supra note 26. 
An objection to the constitutionality of the RFRA has been raised based on the Establishment Clause. ${ }^{415}$ By passing a law affecting religion, RFRA critics believe that the law would thereby become a "law respecting an establishment of religion" as prohibited by the First Amendment. ${ }^{416}$ But the RFRA specifically declares that "[n]othing in this Act shall be construed to affect, interpret, or in any was address that portion of the first article of amendment to the Constitution that prohibits laws respecting the establishment of religion. ${ }^{417}$ As Professor Douglas Laycock declared to Congress, " $[t]$ he fear that this proviso will codify current interpretations of the Establishment Clause borders on the irrational. . . . [A] bill cannot codify something that it neither affects, interprets, or addresses. ${ }^{n 18}$

A statute challenged under the Establishment Clause is constitutional under the prevailing test if it meets three criteria: "[f]irst, the statute must have a secular legislative purpose; second its principal or primary effect must be one that neither inhibits nor advances religion; finally the statute must not foster 'an excessive government entanglement with religion." 419 The RFRA's purpose is certainly not to advance any particular religion. Nor is its purpose to advance religion at the expense of nonreligion or vice versa. Rather, the stated purpose of RFRA is "to restore the compelling state interest test" and "to provide a claim or defense to persons whose religion is burdened by government. ${ }^{n 420}$ The RFRA places all free exercise claims on the same footing, regardless of their source.

For the same reason, the RFRA's effect will not be to advance or inhibit religion. To hold that the RFRA advances religion over nonreligion would require holding that the Court's interpretation of the Free Exercise Clause itself, which embodied a compelling state interest test for nearly thirty years, violated the Establishment

415 See 1992 RFRA Hearings, supra note 4 (statement of Professor Robert A. Destro at 15) (arguing that the RFRA as currently drafted might violate the Establishment Clause).

416 U.S. CONST. amend. I.

${ }^{417}$ H.R. 2797, 102d Cong., 1st Sess. $\$ 7$ (1991). 24).

4181992 RFRA Hearings, supra note 4 (statement of Professor Douglas Laycock at

${ }^{419}$ Lemon v. Kurtzman, 403 U.S. 602, 612-13 (1971) (quoting Walz v. Tax Comm'n, 397 U.S. 664, 674 (1970)) (citations omitted); see also Lee v. Weisman, 112 S. Ct. 2649, 2655 ("[W]e do not accept the invitation of petitioners and amicus the United States to reconsider our decision in Lemon v. Kurtzman.").

${ }^{120}$ H.R. 2797 \& 2(b). 
Clause by protecting religious conduct. Finally, the RFRA would not foster an entanglement with religion. Quite the contrary, by prohibiting government from burdening religious conduct, the RFRA would prevent entanglement between government and religion. The creation of a religious exemption from generally applicable laws no more violates the Establishment Clause than the exemption of religious organizations from property taxes. ${ }^{421}$

An objection to the RFRA has also been raised on Separation of Powers grounds. ${ }^{422}$ However, the Court's latest treatment of the Separation of Powers doctrine casts doubt on this objection. In Robertson $v$. Seattle Audubon Society, ${ }^{423}$ the Court upheld a federal statute that declared that the government had met the requirements of various environmental statutes "that are the basis for the consolidated cases captioned Seattle Audubon Society et al., v. F. Dale Robertson, Civil No. 89-99 (order granting preliminary injunction) and the case Portland Audubon Society et al., v. Manuel Lujan, Jr., Civil No. 87-1160-FR. ${ }^{424}$ The Court explained that since Congress had effected "changes in the law" 425 rather than compelled the result in a particular case, Congress had not violated the Separation of Powers doctrine. If the statute at issue in Robertson effected changes in the underlying law and did not "prescribe a rule for the decision of a cause in a particular way, ${ }^{426}$ then the RFRA, which prescribes a general set of rules to be applied in all free exercise cases, would also simply effect changes in the law. The RFRA would be a valid exercise of Congress's enforcement power. ${ }^{427}$

421 See Walz, 397 U.S. at 680. at 15).

422 See 1992 RFRA Hearings, supra note 4 (statement of Professor Robert A. Destro

423112 S. Ct. 1407 (1992).

124103 Stat. 745 (1990), quoted in Robertson, 112 S. Ct. at 1411. The statute allowed logging in old growth forests containing an endangered species-the northern spotted owl.

425 Robertson, 112 S. Ct. at 1413.

426 United States v. Klein, 80 U.S. (13 Wall.) 128, 146 (1871).

427 An argument can also be made that the RFRA is a valid exercise of Congress's power under the first Morgan rationale. Like the denial of a fair criminal trial and the denial of control over one's own body, the denial of religious rights would compromise the ability of religious minorities to participate equally in a democratic society. The Smith case demonstrates this principle: Oregon fired Alfred Smith and Galen Black for their religious conduct and denied them unemployment benefits. This risked their ability to feed, clothe, and house themselves. When members of the polity are unable to provide for such basics, they cannot effectively exercise their political rights. This approach to the RFRA would likely also pass the Morgan test, 


\section{CONCLUSION}

The precise boundaries of Congress's power under Section 5 of the Fourteenth Amendment cannot, of course, be settled here. For purposes of the RFRA, the FOCA, and the RJA, the boundaries need not be set because those bills are clearly within Congress's established power. It is also clear that the Americans With Disabilities Act of 1990, as applied to the states, is a valid exercise of Congress's section 5 power, as is the prohibition of discriminatory effects in the Civil Rights Act of 1991, as applied to the states, as would be an amendment to Title VII prohibiting sexual orientation discrimination in employment. Perhaps those who fear that Congress's section 5 power endangers the principle of Marbury can be comforted by something Justice Frankfurter said: "the ultimate touchstone of constitutionality is the Constitution itself and not what we have said about it. ${ }^{\text {n428 }}$

There is very little reason to fear that Congress's power under the Civil War Amendments endangers the principle of Marbury: by virtue of its holdings in South Carolina, Morgan, Mitchell, City of Rome, Metro Broadcasting, and Fitzpatrick, the Court implicitly ratified Congress's expansion of rights and thereby secured its own supremacy in defining rights. No one argues that because Congress acted under the enforcement powers of the Civil War Amendments the Court lacked jurisdiction to hear those cases. Professor Tribe, who has urged Congress to pass the RFRA, the FOCA, and the RJA, has declared that "Congress may not legislatively 'create' constitutional rights as a means of circumventing the authority of the Supreme Court as final expositor of the meaning of the Constitution. ${ }^{\text {"429 }}$ Congress can, however, "when authorized by its enumerated powers and not prohibited by any constitutional provision or principle, establish statutory rights in areas that are of legitimate national concern." ${ }^{430}$ Put another way, "being 'ultimate interpreter,' . . . is not the same as being exclusive interpreter. ${ }^{431}$

since the Court need only find that Congress might have perceived such a basis for RFRA.

${ }^{428}$ Graves v. New York ex rel. O’Keefe, 906 U.S. 466, 491-92 (1939) (Frankfurter, $\mathrm{J}$, concurring).

${ }^{429} 1992$ FOCA Hearings, supra note 276 (statement of Professor Laurence H. Tribe at 2).

$430 \mathrm{Id}$.

431 Fisher, supra note 158, at 715. 
The voting rights cases and Fitzpatrick are best viewed as examples of constitutional growth through inter-branch debate. The Court issues a thesis; Congress issues an antithesis; the Court issues a synthesis. So long as the Court retains the power to review acts of Congress-and no one contends that it does not-then there is absolutely no need to fear that congressional power under the Civil War Amendments endangers the Court's authority. 


$$
\text { - }
$$

